\title{
Infectious Diseases
}

\section{Annual review of significant publications}

\author{
Hobart A. Reimann \\ M.D. \\ The Hahnemann Medical College and Hospital, Philadelphia, U.S.A. 19102
}

\section{Introduction}

Beneficial and harmful effects of antimicrobic therapy and the introduction of new agents, as usual, were subjects of interest in 1967. Most attention, however, was given to viruses and viroses, but with the exception of mycoplasmal infection, reports dealing with involvement of the respiratory tract were fewer than in previous years. As new features, the probable viral cause of infectious mononucleosis was discovered and DNA (deoxyribonucleic acid) was synthesized. Because predicted serious epidemics of influenza $\mathbf{A}_{2}$ did not occur, little opportunity was offered to test the prophylactic value of amantadine. The cause of 'viral' hepatitis remains enigmatic and the relation of viruses to neoplasms in man still is unclear. Venereal diseases continue to increase in incidence. Iatrogenic and noscomial infections caused further concern.

\section{Antimicrobial drugs}

In the United States, 865 tons of penicillin G and 75 tons of semisynthetic penicillins were made in 1964 at sales value of $\$ 127$ million (£53 million). Sales of tetracyclines amounted to $\$ 100$ million ( $\$ 41.5$ million) a year. ${ }^{1}$ Antimicrobics comprized more than $50 \%$ of all medicinals in written prescriptions. ${ }^{2}$ In hospitals, antimicrobics were ordered oftener than any other drugs excepting analgesics. Some patients received twelve antimicrobic agents. 'The extraordinary frequency and variability of antibiotic drug practice points out the need and importance of further studies'3 which is mild critique, to say the least. An estimated 6\% of the population now is sensitive to penicillin. Penicillin caused allergic reactions in $10-39 \%$ of known sensitized patients. All penicillins and occasionally cephalosporins are immunologically cross-reactive. ${ }^{4}$ The removal of protein and peptide residues of penicillin eliminated the allergic reactions incident thereto..$^{5}$ Harmful iatrogenic results of therapy will not diminish until medical personnel are better informed about bacteriology and proper antimicrobic therapy. ${ }^{6}$

In tests on 25,000 strains of bacteria, synthetic penicillins inhibited $99 \%$ of staphylococci and penicillin $G$ only $45 \%$. Infection caused by tetracycline-resistant pneumococci and group $\mathbf{A}$ streptococci have increased. Gram-negative bacilli also increased in incidence and are more resistant to antimicrobics than Gram-positive bacteria. $^{7}$

Ampicillin is effective against pneumococci, hemolytic streptococci, meningococci, gonococci, non-penicillinase-producing staphylococci, enterococci, $H$. influenzae, and against many strains of Esch. coli, Salmonella, Shigella and Proteus mirabilis. Klebsiella, Aerobacter and Pseudomonas are resistant. 8 Strains of staphylococci resistant to methicillin appeared. One resisted, in addition, penicillin, erythromycin, kanamycin, chloramphenicol, tetracycline and cephalothin. ${ }^{9}$ Ampicillin was effective in treating listeriosis as reported in two papers in the 16 June 1967, issue of Deutsche Medizinsche Wochenschrift, but not for typhoid.10 A severe methicillin-resistant staphylococcal infection was successfully controlled with vancomycin.11 Vancomycin is ototoxic and nephrotoxic. As yet staphylococci have not become resistant to it but may if the drug is widely used. The report of a conference on broad-spectrum penicillins and other antimicrobics was published. ${ }^{12}$

Streptomycin-dependent bacteria also depend upon unrelated drugs which act similarly on the ribosome to induce the requirement. ${ }^{13}$ Kanamycin and neomycin have the broadest range of activity against Gram-negative bacilli. Kanamycin being less toxic is preferred for initial treat- 
ment, pending the results of sensitivity tests. A safer drug should be substituted if the tests so indicate. Kanamycin was consistently effective in vitro against Klebsiella, especially in combination with cephalothin. ${ }^{14}$ Pseudomonas resists kanamycin and is combatted with polymyxin B (Aerosporin) or polymyxin E (Colistimethate) together with kanamycin or ampicillin. ${ }^{15}$ Topically applied neomycin failed to eradicate bacteria from dermal lesions. ${ }^{16}$ For superficial wound infections, dressings soaked with acetic acid inhibited the growth of Pseudomonas. ${ }^{17}$

Klebsiella and Esch. coli often resisted more than three antimicrobics. Experimentally, Klebsiella transferred multiple antimicrobic resistance to a susceptible strain of Esch. coli. ${ }^{18}$ The transmitting or $\mathbf{R}$ factor also may involve Salmonella and Shigella especially in hospitals. ${ }^{19}$

\section{Antimicrobic prophylaxis}

Conflicting opinions persist. For the treatment of severely burned patients, the following regimen in maximal tolerated dosage was applied: chloramphenicol to suppress Gramnegative bacilli, penicillin for streptococci and clostridias, methicillin for staphylococci. Polymyxin, lincomycin, gentamycin and cephalothin were added on occasion and $\gamma$-globulin was given to 'potentiate the antimicrobic effects'. Chloramphenicol, neomycin, polymyxin and mycostatin were applied topically. No evidence of toxicity, no deaths, and no superinvasion of bacteria were recorded. Intensive prophylaxis, it was said, 'may' have merit, ${ }^{20}$ but admittedly, the mortality-rate was no better than at other 'burn centers'. According to Meade, chemoprophylaxis is of no value in preventing infection in burned patients. Therapy may simply select out the organism which may eventually infect the patient. ${ }^{21}$ Weinstein said 'most experience indicated that if the purpose of prophylaxis is to prevent invasion of any, other than a single species, organism that happens to be present... and this frequently involves the use of broad-spectrum antimicrobial drugs or combinations-then the chances for failure are very close to 100 percent'.21

Antimicrobics should not be administered orally preparatory to surgery on the intestinal tract unless anterior resection with extraperitoneal anastomosis is to be done. Staphylococcal enteritis occurred oftener in patients who received antimicrobics than after mechanical preparation. ${ }^{22}$ Penicillin given during cardiac catheterization failed to prevent bacteremia. ${ }^{23}$ Antimicrobic prophylaxis during cardiac surgery still is widely used, but its value is unproved. ${ }^{24,}$. 24a
Continuous antimicrobic prophylaxis failed to influence the course of chronic bronchitis in Holland. ${ }^{25}$

\section{New antimicrobic drugs}

According to two papers in the January 1968 issue of Archives of Internal Medicine, the value of cephaloridine was similar to that of other agents. The usual side-effects of superinfection with resistant bacteria, nephro- and hemotoxicity ensued. It was effective for pneumococcal pneumonia, ${ }^{26}$ and more active against staphylococci than methicillin. Pseudomonas and indoleproducing Proteus were resistant, but for other Gram-negative bacilli, cephaloridine was equal to cephalothin. ${ }^{27}$ The proceedings of a conference on the drug were published in a supplement to this Journal. ${ }^{23}$

Therapeutically hetacillin is inferior to ampicillin from which it is derived. ${ }^{29}$ Carbenicillin, a penicillin relative, affects especially Pseudomonas and Proteus. ${ }^{30}$ Gentamycin, a relative of neomycin and kanamycin, has a similar spectrum of antimicrobic activity, and the same ototoxicity as discussed editorially and in four papers in the 27 May 1967 issue of British Medical Journal. Some pseudomonal ino fections were treated successfully, others were not. The maximum dosage usually is $240 \mathrm{mg}$ dailyo

Spiramycin (Rovamycin) was said to be effec tive as a prophylactic against staphylococcal infection after prostatectomy. ${ }^{31}$ In monkeys infected with penicillin-resistant staphylococci, cloxacillin and, surprisingly, oleandomycin which is bacteriostatic, were superior to erythromycin for therapy. ${ }^{32}$ More than fifty newly-named antimicrobics were discussed in a book. ${ }^{33}$ How many of them will survive the test of time?

\section{Harmful effects of antimicrobic drugs}

Daily dosage of $40-60$ million units (24 to $36 \mathrm{~g}$ ) of penicillin controlled Gram-negative bacillary infections, but caused transient neurotoxicity. ${ }^{34}$ Encephalopathy ensued in uremic patients after 30 million units $(18 \mathrm{~g}) .^{35}$ Three elderly patients with suspected Gram-negative bacillemia and decreased renal function died from neurologic disturbance after the intravenous injection of similar huge amounts. In a fourth nonfatal case, convulsions ceased when therapy was stopped. ${ }^{36}$ One may wonder how often death from therapy is regarded as death from disease. Mental disturbance alone was thought to be an immediate pseudoanaphylactic response which differs from anaphylactic shock and circulatory failure. It did not seem to indicate cessation of therapy. ${ }^{37}$ In an unusual case, an immediate 
anaphylactoid reaction was followed 2 weeks later by 'serum sickness'38

Acute renal failure ensued during therapy with methicillin, ${ }^{39}$ polymyxin $B,{ }^{40}$ kanamycin, bacitracin, neomycin, and colistin. Early use of hemodialysis meliorated the harm. ${ }^{41}$ Kunin published a guide to the safer use of antimicrobics during renal failure. Harm from nephrotoxicity is reversible if therapy is stopped soon enough. ${ }^{42,42 a}$

Tetracycline given intravenously caused fatty change in the liver of six non-pregnant women..$^{3}$ Two icteric patients who had received large doses of tetracycline postoperatively died from hemorrhage possibly the result of disturbance of the clotting mechanism.44 Oleandomycin, novobiocin, chloramphenicol, amphotericin, sulfonamides and isoniazid have been implicated as causes of hepatic disturbance. ${ }^{45}$ In ten patients, pneumonia followed within a few hours of therapy with nitrofurantoin. Chills, fever and leukocytosis with eosinophilia disappeared when the drug was stopped. ${ }^{46}$

Reports of 408 cases of chloramphenicol-associated hemal depression were reviewed. Regrettably, the drug had been administered mostly to patients with the 'common cold' for which no antimicrobic is needed, for pneumonia for which other drugs are available, and for lower genitourinary tract infections. Gonorrhea, the commonest of the latter, is better treated with other drugs. Marrow toxicity occurs after large or small doses or short or long courses. The risk of its occurrence is low but the risk of fatality is great. Evidence of damage usually appears after therapy ceases, and leukocyte counts made during therapy are of little value in predicting toxicity. ${ }^{47}$ A positive direct Coombs' test reaction was noted in $75 \%$ of patients who received cephalothin especially in azotemic ones. ${ }^{48}$ Cephalothin induced thrombocytopenia in a patient sensitive to penicillin. ${ }^{49}$

During a 2-month period, of eight patients who underwent open-heart surgery five developed respiratory tract infection with $P$ s. aeruginosa type 10 and three died. All had received ampicillin and methicillin prophylactically. ${ }^{50}$ Granulomatous hepatic and pulmonic lesions discovered by biopsy followed dosage of $2 \mathrm{~g}$ of sulfadimethoxine given for sore throat. ${ }^{51}$ Sulfonamide drugs on successive occasions incited attacks of hiccough without other evidence of toxicity. ${ }^{52}$ Antimicrobic therapy may mask acute otitic infection while complications progress unrecognized. ${ }^{53}$ Because of the universal use of antimicrobics, Monilia has displaced Trichomonas as the cause of vaginitis. ${ }^{54}$ A $15 \%$ incidence of dermal eruptions during infectious mononucleosis, increased to $45 \%$ during antimicrobic therapy..$^{55}$

\section{Viral infections}

\section{Respiratory tract infections}

Among infants, acute pharyngitis usually was of viral origin. Between ages 6 and 8 years hemolytic streptococci caused illness in more than half. Mycoplasma pneumoniae affected adolescents only. Etiologic diagnosis rarely can be made clinically ; epidemiologic factors, the age of patients, the season and current prevalence of identified microbic infections are more helpful. Recognition of hemolytic streptococci as causes is of special value. Even so, streptococci were present at the same rate in 6-year-old well children.58 They also may be present during viral infections. Respiratory syncytial virus caused most infections, especially pneumonia in children less than 1 year old. Parainfluenza viruses 1 and 3 caused less severe illness, and mycoplasmal infection usually was mild. Streptococci and pneumococci rarely caused pneumonia in children. ${ }^{57}$ In older children, $17 \%$ of respiratory tract infections were caused by viruses and bacteria together, and in $20 \%$ by more than one virus at once. ${ }^{58}$ Viral respiratory tract infections did not seem to predispose to the invasion or dissemination of meningococci. ${ }^{59}$

\section{Rhinovirus}

Besides changes in weather, factors such as cosmic rays or light cycles may influence seasonal epidemics of acute respiratory tract disease..$^{60}$ In agreement with the early studies of Andrewes, exposure to cold and chilling failed to increase the incidence of infection or its severity in volunteers inoculated with rhinovirus. ${ }^{61}$ In my personal experience, chilling induced severe respiratory tract infections in at least two instances.

From young children with afebrile colds, twenty-six rhinoviruses mostly of types 16,38 , and a new $H$ group serotype 54 were recovered. The isolation-rate was $3.5 \%$ as compared with $15 \%$ in adults with respiratory tract infections. ${ }^{62}$ In a hospital, seventy-three infants and children were infected with rhinoviruses chiefly of the ' $H$ ' strain. Eight had viral pneumonia. ${ }^{63}$ Rhinovirus illness usually lasted about 1 week in young adults. The development of antibody in most patients probably is a factor in preventing reinfection. ${ }^{64}$ Rhinoviruses do not survive in the intestinal tract. ${ }^{65}$ Rhinovirus often incites exacerbations of chronic bronchitis. ${ }^{66}$ Osler's 
description of the common cold in 1892 has never been surpassed. ${ }^{67}$

Respiratory syncytial virus seemed to be the chief cause of death among sixteen of twentytwo infants. Nine of these had congenital abnormalities. Bacterial infections were fatal in six. ${ }^{68}$

\section{Influenza}

Influenza $\mathbf{A}_{2}$ virus caused severer illness than B virus among Eskimo children. During several outbreaks, respiratory syncytial, parainfluenza 3, adenoviruses 2 and 5 , rhinovirus and herpes simplex virus also were isolated. Occasionally two viruses were present in one patient. About $50 \%$ of synchronous $\mathbf{A}$ and $\mathbf{B}$ infections were pneumonic. ${ }^{69}$ An $A_{2}$ virus affected about $60 \%$ of dental students and some patients who had visited a dental clinic. Prior vaccination against influenza was not effective. ${ }^{70}$ Dentists are liable to infection with aerosolized virus exhaled by patients.

According to present information, amantadine hydrochloride is useful only for the prevention of influenza $\mathbf{A}_{2}$, but its premature commercial availability may lead to indiscriminate use against any viral infection, and its possible adverse reactions are unknown. ${ }^{71,71 a}$ The drug seemed to worsen the effects of rubella, and was not recommended for general use pending further information. ${ }^{72}$

Parainfluenza virus was present in the air near a sick child and infection evidently can be airborne. $^{73}$ Paramyxoviruses in the pharynx are easily detectable and diagnosis is possible within $1 \mathrm{hr}$ by applying electron-microscopic technique. ${ }^{74}$

\section{Adenovirus}

Physicians hesitate to ascribe fatal pneumonia to viral origin and generally use the phrase 'associated with' rather than 'caused by'. Death in an adult was associated with adenovirus $4^{75}$ and in a child with Reovirus $3 .^{78}$ Adenovirus 7 caused fatal pneumonia and pericarditis in an infant. ${ }^{77}$ Adenovirus 3 and Mycoplasma pneumoniae caused unilateral deafness in two instances. ${ }^{78}$

\section{Newly recognized viruses}

Eight hitherto unknown viruses were isolated from patients with acute upper respiratory tract infections. By electron-microscopy some of them resembled avian bronchitis virus but were distinct from myxoviruses. ${ }^{79}$ A newly isolated virus, Fermon, probably of the picorna group was obtained from children with viral pneumonia. ${ }^{80}$ An agent regarded as Ryan virus isolated from patients with respiratory tract infections later was identified as an ameba (Hartmannella), the clinical significance of which is uncertain. ${ }^{81}$ Specific antibody was present in $20 \%$ of patients. ${ }^{82}$ Amebas of that group were isolated from the pharynx of healthy persons especially children. ${ }^{83}$ As mentioned later, amebas also caused encephalitis. These reports resurrect Kofoid's views of amebic infections 35 years ago.

Another 'new' virus resembling the avian bronchitis agent isolated from the throat of a patient caused mild infection in inoculated volunteers. Blood from $29 \%$ of persons in Britain contained neutralizing antibody. ${ }^{84}$

\section{Herpes simplex}

Herpes simplex virus heretofore considered as relatively unimportant gained much attention. Disseminated herpes simplex infection occurs more often than believed especially in children whose resistance is impaired. In South Africa ninety-three cases were recognized. ${ }^{85}$ Diagnostic methods were described. ${ }^{86}$ The frequent presence of herpes virus in the throat needs further investigation as to its possible role in causing pharyngitis and pneumonia. The virus could be isolated and identified in 4 days. Accurate diagnosis obviates unwarranged antimicrobie medication. ${ }^{87}$ Idoxyuridine is believed to cure herpetic keratoconjunctivitis, but if it also hastens? recovery from chemically-induced keratitis, ${ }^{88}$ perhaps its action is nonspecific and not antiviral.

\section{Infectious mononucleosis}

Recent investigations revealed unsuspected viral relationships and the long-sought cause of infectious mononucleosis. Cytomegalovirus, a relative of herpes simplex virus, caused mononucleosis-like disease ${ }^{89}$ and hepatitis. ${ }^{90}$ By serendipity, the Henles educed evidence that a herpes-like virus, related to the virus obtained from Burkitt's sarcoma, causes infectious mononucleosis. The virus was visualized by immunofluorescent technique in patients and specific antibody was present in $80 \%$ of a population. ${ }^{91}$ It must be determined if the three viruses mentioned actually are causes of the respective diseases or commensal. Indirect immunofluorescence in biopsy specimens localized a specific heterophile reactive antigen in the kidneys. ${ }^{22}$

Recurrent attacks of erythema multiforme after herpetic lesions of the face suggested that hypersensitivity to herpes simplex virus resulted in the generalized vesicobullous eruption. ${ }^{93}$ Herpes simplex virus inoculated intravenously in pregnant rabbits induced viremia and killed $30 \%$ of the fetuses. ${ }^{94}$ 
Slow viruses

Herpes simplex virus, rubella virus and cytomegalovirus can penetrate the placenta and incite chronic infection as 'slow' viruses. Rubella virus persisted in the lens of an infant for 3 years after infection. ${ }^{95}$ Failure to produce interferon in culture, and insensitivity to the antiviral action of interferon in the circulation, may account for the persistence of cytomegalovirus. ${ }^{96}$ Failure to terminate the excretion of rubella virus may be due to a defect of the cellular immunefunction of lymphocytes injured by the virus. ${ }^{97}$ As in human infants with congenital rubella, rubella virus inoculated into newborn ferrets caused chronic inapparent infection detectable for a year. ${ }^{98}$ Current knowledge of slow viruses was summarized in a book. ${ }^{99}$

The causal agent of scrapie was said to be smaller than any known virus. It survives rapid freezing and thawing, boiling for $30 \mathrm{~min}$ and exposure in $10 \%$ formalin, but is inactivated by urea. No particles were visualized by electronmicroscopy. It may be either a microbe or nonliving matter. ${ }^{100}$

\section{Encephalitis}

Herpes simplex came to attention as an important cause of encephalitis. ${ }^{101}$ It accounted for about $10 \%$ of cases. ${ }^{102}$ In one study the virus was recovered from the brains of five patients, four of whom died. ${ }^{103}$ In another report, diagnosis also was established by isolation of the virus from the brains of four children. One who recovered had received idoxyuridine. ${ }^{104}$ Dermal or mucosal lesions seldom aided diagnosis; biopsy was needed. In other victims described in the 13 May 1967 issue of British Medical Journal, recovery occurred in two patients treated with idoxyuridine, but serious physical and mental impairment ensued. Among forty-nine other cases, thirty-four were fatal. If $30 \%$ of untreated patients recover, the therapeutic value of idoxyuridine is questionable.

Fifteen per cent of patients died during the Texas epidemic of St Louis encephalitis. Onethird of them had other underlying disease. ${ }^{105}$

The mortality-rate in general is much lower if all mild and unrecognized cases are included statistically. ECHO virus causes meningoencephalitis, transverse myelitis and probably other neurologic diseases. ${ }^{106}$ Central European encephalitis caused by an arbo virus is less severe than the Russian spring-summer disease. ${ }^{107}$ Although rabies is considered to be fatal invariably, Rumanian physicians state that with modern methods of therapy some patients recover. ${ }^{108}$ This remains to be proved. Recom- mendations for the prevention of rabies were outlined. ${ }^{109}$ Vaccine prepared in chick or duck embryo cells induced neutralizing antibody in volunteers. Immunization before infection was recommended for veterninarians and others especially exposed to rabies. ${ }^{110}$

Electron microscopy disclosed inclusion bodies, like those associated with myxovirus, in the brain in two instances of subacute inclusion-body encephalitis. One of the patients had been exposed to canine distemper. ${ }^{111}$ Viruses reach the central nervous system via neural, olfactory and especially the hematogenous routes. The existence of a 'blood-brain barrier' is doubtful.112

Amebas of the genus Hartmannella and Naegleria acquired during swimming caused fatal encephalitis. ${ }^{13}$

In 1966, the incidence of paralytic poliomyelitis in the U.S.A. was the third lowest recorded. During an epidemic in Texas, sixty-six unvaccinated children were stricken, bringing the total number to 102 cases. Five instances of paralytic disease occurred as vaccine-associated cases in vaccinees, and four instances of the disease occurred in contacts of vaccinees. ${ }^{114}$

\section{Measles}

Measles virus may attack the kidneys. By immunofluorescent procedure, measles antigen was observed in the mucosa of the bladder, and in cells of the tubules and epithelium of Bowman's capsule. Exfoliated giant cells and cells with inclusion bodies appeared in the urine. ${ }^{115}$

Antibody against measles virus was detected in victims of multiple sclerosis.116 One study confirmed Adams' observation, ${ }^{117}$ another did not.118 Suggestion of a delayed autoimmune reaction as a cause was made. ${ }^{117}$, 117a Some forms of chronic encephalitis may be caused by latent measles virus. ${ }^{119,} 120$ The subject was discussed at a conference. ${ }^{121}$ Similarly, Dawson's encephalitis may ensue from infection with a 'slow virus'.117a

\section{Mumps}

An epidemic of mumps involved 119 of 212 natives in an area of Alaska free from infection for 60 years. Six persons who had had mumps in 1907 were not reinfected, suggesting the existence of durable immunity. Hyperimmune $\gamma$-globulin administered prophylactically to fiftysix susceptible persons failed to provide immunity and was not recommended for prevention.122

The attack rate of mumps in children vaccinated with an attenuated live virus was $2 \%$ as compared with $61 \%$ in control subjects. Protection lasted as long as 8 months and may be perm- 
anent. ${ }^{123,}{ }^{124}$ There is question as to the need for mass vaccination of children for so mild an infection. In rare instances, mumps causes serious orchitis $^{124 a}$ and still rarer neurologic disturbances. Mumps caused spinal paralysis in two sisters. ${ }^{125}$

Illingworth called attention to the futility of enforced bed-rest, dietary restriction, medication and quarantine for children with rubeola, rubella, varicella and mumps. ${ }^{126}$

\section{Coxsackie}

A large outbreak caused by $A_{9}$ virus affected a community in 1963 . About $88 \%$ of susceptible persons developed antibody to the virus indicating a high degree of communicability. Exanthem, fever, coryza and meningitis occurred. ${ }^{127} \mathbf{B}_{5}$ virus was usually prevalent in Britain in 1965 affecting chiefly the respiratory and intestinal tract of children. After age 10, neural and muscular disturbance predominated.128

Coxsackie viral myocarditis occurred in twenty patients, thirteen of whom had infection of the respiratory tract. Transient cardiomegaly appeared in eleven, leukocytosis in fifteen and recurrence followed in eight. ${ }^{129}$ From fifty-five hearts examined post-mortem, antigens for Coxsackie viruses were demonstrated in the myocardium of seventeen and in the mitral valve of three. Chronic, focal interstitial lesions were seen. ${ }^{130}$ B virus caused pneumonia in infants. ${ }^{131}$ Although the incidence of spontaneous abortions increased in Hungary after a large epidemic caused by Coxsackie $B_{3}$ virus, the incidence of stillbirths and premature births did not. ${ }^{132}$ Virus $A_{16}$ was implicated in forty children with 'hand, foot and mouth disease'. In two instances, the presence of herpes simplex virus caused diagnostic perplexity. ${ }^{133,}$ 133a

\section{Miscellaneous viral infections}

ECHO type 30 virus caused an epidemic in England.134 ECHO 9 virus caused fatal myocarditis. ${ }^{435}$

Complications of varicella or herpes zoster in pregnant women may not be so serious as feared. Of eleven victims, only one had nephritis and hepatitis. Seven women delivered normal fullterm infants; three others with neonatal varicella recovered. ${ }^{136}$ Serologic evidence of past or present cytomegaloviral infection was detected in half of forty-two children of migrants, aged 1-13 years. One-third of those less than 4 years old had viruria. ${ }^{137}$ Evidence of cytomegaloviral infection was present in $52 \%{ }^{138}$ and in $73 \% 139$ of patients who had had renal transplants. For leukemic children under intensive chemotherapy, floxuridine given with prednisone seeemed to cure cytomegaloviral infection. ${ }^{140}$

A veterinarian contracted foot-and-mouth $\stackrel{D}{2}$ disease type C.141 A serious epizootic of foot- $\stackrel{c}{.}$ and-mouth disease affected cattle in England. ${ }^{142} \Rightarrow$ Vesicular stomatitis caused mild influenza-like $\stackrel{0}{\circ}$ illness in persons in contact with sick animals. 을 Diagnosis was possible only by serologic $\frac{\overline{7}}{\bar{N}}$ methods. ${ }^{143}$ A newly recognized disease in $\frac{\bar{D}}{\Phi}$ Germany among handlers of African monkeys $\stackrel{\mathbb{\Omega}}{\Omega}$ was said to resemble a pox-like infection and hemorrhagic fever. ${ }^{144}$ Marburg virus was the $\vec{\theta}$ cause. ${ }^{145}$

More than 1500 instances of infections acquired in laboratories resulted in thirty-nine deaths. Arboviruses especially of Group B accounted for 126 cases in 1967. Infections followed contact with infected animals and inhalation of aerosolized viruses. Many inapparent and mild infections no doubt are unrecognized. ${ }^{146}$

An attack-rate of $50 \%$ characterized an epidemic of dengue in Puerto Rico.147 Chikungunya virus and dengue type 2 virus were present in blood from a patient with dengue-like disease. Antibody to both viruses increased. ${ }^{148}$ The lesions of Bolivian hemorrhagic fever chiefly involved the reticulo-endothelial organs wits $\vec{\bullet}$ hyperplasia and edema. Hemorrhage and conges tive changes are common to viral hemorrhagie. diseases including yellow fever.149 Filament? resembling myxovirus in nuclei and cytoplasm of degenerating muscle tissue during chronic polymyositis may be a cause of the disease. ${ }^{150}$

A variety of viruses, especially of the exanthems, interfere with the clotting of blood. They affected platelets, injured endothelium and caused hemolysis and disseminated intravascular coagulation. ${ }^{151,} 152$

The May 1967 issue of British Medical Bulletin contains sixteen articles on aspects of medical virology. Reviews of viral infections of the joints $^{153}$ and of the kidneys ${ }^{154}$ were published. The scientific aspects of the synthesis of DNA in vitro were presented. ${ }^{155}$

\section{Viruses and tumors}

Particles resembling herpes virus in cultured lymphoma cells were able to infect, to reproduce and to kill the cells in vitro and in vivo. The agent caused encephalitis in inoculated animals. Similar particles also were present in other cancer cells and in normal human leukocytes. To cause leukemia, the virus probably is activated when helped by unknown factors. ${ }^{156}$ Inclusion bodies found in leukemic marrow cells in a patient resembled those present in a variety of other diseases and probably are not of viral origin. ${ }^{157}$ 
Electron microscopy disclosed viral particles in cells from patients with Burkitt's lymphoma. The virus appeared to originate in nuclei and emerge from cells by budding. ${ }^{158} \mathrm{~A}$ herpes-type virus obtained from cultured Burkitt cells induced a persistent chromosomal lesion and often enabled a continuous growth of hematopoetic cells. ${ }^{159}$ A related virus probably causes infectious mononucleosis as mentioned previously. An unknown virus was isolated from Burkitt lymphoma cell cultures superinfected with a sarcoma virus. Its causal relationship was undetermined. ${ }^{160}$ The problem of viral oncogenesis was discussed editorially ${ }^{161}$ and an extensive review of research on viruses and cancer was published. ${ }^{162}$

Rous in his Nobel lecture stated 'No virus has yet been found that indubitably actuates tumors in man. Yet this is not to say that viruses play no part in initiating them occasionally'.163 According to Dameshek, there is no evidence that viruses cause leukemia in man. ${ }^{164}$

\section{Vaccines}

An attenuated anti-smallpox vaccine awaits field trial. It does not replace the standard vaccine, but seemed to be safer to use in eczematous children. Fever ensued at times. ${ }^{165}$ Warts disappeared after anti-smallpox vaccination in all but one of 165 instances probably as a result of viral antagonism or the action of interferon. ${ }^{166}$ Such success was not attained by others, and reaction may be severe. ${ }^{167}$ Two years after anti-poliomyelitis vaccination, $96 \%$ of children had antibody titers of 8 or more to three types of virus. Antibody to types 2 and 3 declined most except after booster doses. ${ }^{168}$

A symposium of fourteen papers about immunization procedures appeared in the October 1967 issue of the Archives of Environmental Health. The problems and value of vaccines against seventeen viral diseases were discussed.159 Official recommendations about the use of measles vaccine were published. ${ }^{\mathbf{1 7 0}}$

\section{Unwanted effects of vaccination}

Vaccinia after anti-smallpox vaccination in Britain affected an estimated 5 million persons and caused four deaths between 1951 and $1960 .{ }^{171}$ A person who reacted violently to vaccination was the source of an epidemic of vaccinia involving twenty-two people and 450 cows. Milker's nodules were suspected at first. ${ }^{172}$ Anti-smallpox vaccination for the illogical treatment of recurrent herpetic lesions caused death from vaccinia necrosum. ${ }^{173}$

Reaction to live measles vaccine after previous injection of inactivated vaccine suggested discon- tinuance of the latter which is of less value anyway. ${ }^{174}$ Severe measles with pneumonia and unusual eruptions as a result of altered reactivity, affected children 5-6 years after receiving inactivated measles vaccine. 175 Vaccination also caused thrombocytopenic purpura. ${ }^{176,177}$

In Dakar, 243 cases of encephalitis and twentythree deaths, chiefly among children, followed vaccination with antiyellow fever vaccine. The risk was about two cases per $1000 .{ }^{178}$ The tragedy recalls the occurrence of hepatitis after similar vaccination during World War II. Paralytic poliomyelitis caused by a vaccine-like strain of virus affected a child ${ }^{179}$ and a $\operatorname{man}^{180}$ who had had contact with orally vaccinated children. While vaccination might control outbreaks of foot-and-mouth disease in cattle, it will not eradicate infection, but actually may favor its perpetuation. ${ }^{181}$ Among twenty persons who received the Semple rabbit-brain vaccine after exposure to a rabid leopard, thirteen developed lethargy and other unpleasant symptoms 4 days after vaccination began, and nineteen noted erythema, induration and tenderness at the site of injection. Axillary lymphadenopathy occurred in seven and two were severely ill. ${ }^{182}$

Sir Graham Wilson's book discusses the hazards of vaccination, particularly en masse. ${ }^{183}$ Lederberg pointed out possible harmful genetic effects in man after inoculation with live viruses.

\section{Interferon}

A double-stranded RNA injected into mice induced the appearance of interferon which protected them against infection with viruses. ${ }^{185}$ The discovery of interferon raised unfulfilled hopes of its action to prevent or cure viral infections. A substance antagonistic to interferon was discovered which stimulates viruses. The predominant action of either interferon or 'stimulon' may determine the occurrence or the outcome of a viral infection. ${ }^{186}$ Merigan discussed the problems involving interferon and referred to four other reviews of the matter. ${ }^{187}$

\section{Mycoplasma pneumoniae}

Nearly one-half of students admitted to an infirmary had acute respiratory infection. Of 136 with pneumonia, $M$. pneumoniae was the cause in $52 \%$, but in only about $2 \%$ did it cause upper respiratory tract infection. Over a 12-year period, the incidence of pneumonias increased cyclically every 4 or 5 years. ${ }^{188}$ Mycoplasma pneumoniae caused an outbreak of respiratory tract disease in Scotland that persisted from January to June 1965. Symptoms in some victims persisted for weeks. Most were ambulatory, three of forty 
had pneumonia and four had myringitis. ${ }^{189}$ At the same time in West Virginia, among 208 patients with acute respiratory tract disease, sixtyseven were infected with $M$. pneumoniae and of these thirty-seven had pneumonia, five had myringitis and two had otitis media. All recovered. The mean age of victims was 46 years. The infection was suspected but unproved in forty-two other patients. Thirty-four patients had other associated diseases. The average duration of disease was 28 days in non-pneumonic patients and 41 days for the pneumonias. For diagnosis the agglutination test for $M$. pneumoniae was not so sensitive as the complement fixation or immunofluorescent procedures, but it is more reliable than the cold-agglutinin test.190 Therapy with antimicrobics did not give striking results. Fatal infection, acute hemolytic anemia and multiple thrombosis occurred in an aged patient. $M$. pneumoniae was cultivated from the lung and bronchial lymph nodes. ${ }^{191}$

An epidemic of $M$. pneumoniae infection in autumn affected $90 \%$ of children in an institution, especially the mongoloids. About $64 \%$ of adult attendants were infected. The incidence of pneumonia was $28 \%$ in the sick children and $7 \%$ in the adults. ${ }^{192}$ In another study, $M$. pharyngis and $M$. salivarium were present in the throat of many healthy children. $M$. pneumoniae, however, was present in twenty-seven of forty-six children and caused pneumonia in five. ${ }^{193}$ In family studies for 8 months, $50 \%$ of members initially had positive cultures. After 8 weeks, the figure rose to $90 \%$. Pneumonia occurred in fourteen, milder disease in eighteen and inapparent infection in six. Tetracycline failed to influence the course of disease and did not eradicate the microbe. ${ }^{194}$ The microbe rarely causes otitis media. ${ }^{195}$ The causal relation of $M$. pneumoniae to erythema multiforme exudativum was demonstrated culturally and serologically in a patient. ${ }^{196}$

Erythromycin was the most active of twentyone antimicrobics against $M$. pneumoniae in vitro. Penicillin was inactive. ${ }^{197}$ The microbe persisted in the respiratory tract in infected volunteers after therapy with either tetracycline or erythromycin and disease recurred in one instance. ${ }^{198}$ Inactivated vaccine evoked antibody in ten of nineteen volunteers. After a challenge inoculation only one of the ten became sick while respiratory tract infection developed in seven of nine who failed to develop antibody, and in ten of thirteen unvaccinated persons. ${ }^{199}$

A newly-described mycoplasma probably caused spontaneous abortion and inflammation of the fetal membranes. It was present in the urine of both wife and husband. ${ }^{200}$

\section{Viral hepatitis}

Five patients contracted viral hepatitis 49-103 days after exposure to chimpanzees.201 The attack-rate of viral hepatitis among missionaries abroad was $1.6 \%$ to $5.5 \%$ a year. ${ }^{202},{ }^{202 a}$ The virus persists in insufficiently steamed clams. ${ }^{203}$ Serum hepatitis occurred among competitors in cross-country races in Sweden. Infection presumably was acquired through scratches and wounds bathed with polluted water. The outbreak ceased when hygenic principles were observed and recurred when they were discontinued. ${ }^{204}$ An outbreak of serum hepatitis affected twenty-seven narcotic addicts after the use of contaminated syringes and needles. ${ }^{205}$ Cytomegalovirus was present in the urine of two patients with cholestatic hepatitis. ${ }^{208}$ Whether it was the cause or a commensal cannot be said. Toxoplasma caused hepatitis in two adults. The microbe was demonstrated immunofluoroscopically in cells in necrotic areas. Specific antibody appeared in the blood. ${ }^{207}$ No virus particles, no antigen and no cytopathologic effects were observed in a wide variety of cell-cultures inoculated with serum from patients with infectious hepatitis. ${ }^{208} \mathrm{~A}$ different approach and different methods are needed to discover the cause.

\section{Bacillary infections}

\section{Tuberculosis}

Knowledge of tuberculosis acquired since the bacillus first was seen by Robert Koch 87 years ago was reviewed by Myers who himself devoted nearly a half century to studies and control of the disease. ${ }^{209}$ His efforts reduced the incidence of tuberculin reactors in Minnesota from $60 \%$ in 1921 to about $3 \%$ in 1967 . In contrast, today in Saigon, $85 \%$ of adults are reactors. Eventually to eradicate the disease, reactors discovered by the tuberculin test must be controlled and effort made to rid them of the bacilli. This has not been accomplished, and for several reasons may never be.

Confusion exists as to whether hypersensitivity to tuberculoprotein is beneficial or hazardous. In itself it probably is neither, but is an indication of the presence of infection. Reactors to tuberculin are already infected and their chance of developing chronic tuberculosis is greater than for nonreactors. $^{209}$ Non-reactors may of course be primarily infected and become reactors. ${ }^{210,} 211$ Vaccination with BCG was advocated ${ }^{212}$ but it induces hypersensitivity and thus destroys the value of the skin test to discover infected persons. The weak immunity afforded by vaccination does not rid the body of tubercle bacilli. 
Chemoprophylaxis with isoniazid was recommended officially for persons with apparently inactive tuberculosis, for ex-patients, for those with significant roentgenographic pulmonic changes who react to tuberculin, and for reactors whose roentgengrams show no lesions, especially if reaction to the dermal test changes from negative to positive. ${ }^{213}$ Prophylaxis with isoniazid reduced the incidence of tuberculosis about $60 \%$ in a heavily infected population in Alaska. ${ }^{210}$ After nearly 3000 tuberculin-positive schoolchildren received isoniazid for a year only one case of tuberculosis occurred, as compared with twenty-five cases among 1192 untreated reactors. The cost of treatment per person was $\$ 80 . .^{214}$

Several 'micro-epidemics' occurred on shipboard among naval personnel. Isoniazid given prophylactically to reactors caused reversion in most of the recent converters, but not in those with established disease. ${ }^{215}$ Both good and bad long-range effects must be considered. Because the drug is suppressive, infection may be perpetuated and will obstruct eradication.

\section{Therapy}

Pyrazinamide, ethionamide, cycloserine, kanamycin, viomycin, capriomycin and ethambutol were considered as 'second-line' anti-tuberculosis drugs when the usual ones are not given. Each may cause serious toxic effects and should be applied only if the physician has had experience with their use and has facilities available to detect toxicity. ${ }^{216}$ Methylprednisone injected intrathecally for sciatica(!) incited tuberculous meningitis. ${ }^{217}$

Vaccination with BCG was said to prevent leprosy. Four years after vaccination began, nineteen cases occurred among 8000 vaccinees and 143 cases in the control group. ${ }^{218}$

\section{Atypical tubercle bacilli}

In recent years, the reduction in the number of people who react positively to the standard tuberculin test to less than $15 \%$ of a population made it possible to detect widespread inapparent infection with other mycobacteria. According to Smith, atypical mycobacteria now cause more infections in young persons than $M$. tuberculosis. From $15 \%$ to $50 \%$ of recruits reacted to antigens of three atypical tubercle bacilli. Atypical forms reside in soil like Histoplasma and Coccidioides. They were thought not to be transmitted from person to person,,12, 219 but the question arose on shipboard whether or not conversion of tuberculin reactions in some previous non-reactors was caused by inapparent infection with atypical mycobacteria acquired by contact with a carrier. ${ }^{220}$
The medical significance of Mycobacteria other than $M$. tuberculosis still is unclear and their classification is uncertain. Of 291 strains examined, 240 belonged to Group I, three to Group II, fourteen to Group III, nineteen to Group IV and fifteen were unclassifiable. Group I bacilli were the most sensitive to isoniazid. There seemed to be no geographic predominance of distribution. ${ }^{221}$ Low-catalase strains of $M$. kansasii were not associated with disease in man, Group II scotochromogens, Group III nonphotochromogens often were and the remaining subgroups of scotochromogens rarely were. ${ }^{222}$

\section{Salmonellosis}

Outbreaks of salmonellosis originated from pies made with frozen eggs contaminated with different types of salmonellas ${ }^{223}$ and from powdered milk. ${ }^{223 a}$ Salmonellosis occurred in nineteen of 5000 patients with neoplastic disease. Bacteremia occurred in seven and pneumonia, meningitis, peritonitis and urinary tract infection in six others. ${ }^{224}$ Salmonellosis, a common complication of schistosomiasis in Egypt, is essentially a urinary tract infection manifested by long, remittent fever. ${ }^{225}$

Carmine dye, used as a stool marker, contaminated with Salmonella cubana caused infections in patients in hospitals as reported in two papers in the 13 April 1967 issue of New England Journal of Medicine. Salmonella typhi was present in the blood but not in the feces or urine of twelve patients who did not have typhoid. Evidentally in carriers, salmonellas from a residual focus of infection may be shed into the blood as well as the feces. ${ }^{226}$

\section{Dysentery}

More than 500 persons who drank an orangejuice beverage were stricken with nausea, vomiting, diarrhea, headache and fever presumably caused by a virus.227 An attack-rate of $17 \%$ characterized an epidemic of diarrheal disease in a small community. Households were affected. The water supply was suspected as the source, but no bacteria could be incriminated as the cause. ${ }^{228}$ The possibility of air-borne viral dysentery was not mentioned. No causal agent could be identified in jejunal, ileal, or fecal specimens from twenty-nine other adults with acute diarrhea. The chief change was an increased number of bacteria in the jejunum. ${ }^{229}$

During a small outbreak of Sh. flexner dysentery, bacilli resistant to five antimicrobics were excreted. The resistance was transferred to an antimicrobic-sensitive strain. ${ }^{230}$ Coxsackie, ECHO and adenoviruses were present in stools of more than $10 \%$, Shigella and Salmonella in 
$3 \%$ and Esch. coli in $16 \%$ of infants with severe diarrhea..$^{231}$

Whooping cough, at times, is caused by parainfluenza viruses and other microbes. When $B$. pertussis is causal, the term pertussis is preferred. Secondary bacterial complications rarely occurred in 140 cases. ${ }^{232}$

\section{Tetanus}

Nearly three-quarters of known instances of tetanus in New York City occurred in narcotic addicts, mostly in young Negresses in whom the case fatality rate was $87 \%$ compared with $38 \%$ in non-addicted patients. ${ }^{233}$ As had long been suspected, the therapeutic use of antitetanus serum was of no value once the disease is fully developed. ${ }^{234,235}$ Yet, it was said to be beneficial for neonatal tetanus. ${ }^{236}$ The therapeutic effect of hyperbaric oxygen was disappointing. ${ }^{236 a}$ Tetanus toxoid provides immunity lasting 15-20 years. 'Booster' injections should not be given annually. Except in an emergency, a reinforcing dose is recommended at 10-year intervals for previously immunized persons. Otherwise, the population at large will by hypersensitized to toxoid without adding to protection against tetanus. ${ }^{237}$

\section{Plague}

During an outbreak of plague in Vietnam in 1965, Past. pestis was present in the throat of fifteen of 114 healthy persons. ${ }^{238}$ Carriers exist and undiagnosed mild attacks occur which if included statistically increase the incident-rate and lower the usually stated mortality rate. Several patients with bubonic plague were in Saigon hospitals during my presence in April 1967. An American, previously vaccinated, contacted plague and recovered. Vaccination was thought to have conferred some protection ${ }^{238}$ but its value is questionable. Three cases of meningeal plague occurred in children in New Mexico. ${ }^{240}$ As recorded in three papers in the December 1967, Public Health Reports, six Navaho children had plague during an epizootic among prairie dogs.

Tularemia affected 536 persons in Missouri between 1949 and 1965. Ticks were the vectors in $26 \%$ of cases, contact with rabbits occurred in $13 \%$ and in the rest the source was unknown. ${ }^{241}$

\section{Cholera}

Cholera as a unique infectious disease resembles the effects of a hydragogic purgative without inflammation of the enteric mucosa. Suggestion was made that 'choleragen', a product of $V$. comma apart from its endotoxin, does not cause epithelial denudation, does not inhibit the 'sodium pump', nor increase permeability of the membrane, but stimulates epithelial cells to secrete the usual fluid in abnormally large amount. ${ }^{242}$

$V$. comma resident in the gall bladder of convalescent patients may account for the carrier state and serve as a source of infection. ${ }^{243}$ Phillips received a deserved award for his contributions to the knowledge of cholera, but Chinese physicians in 1945 already showed that the mortality-rate could be reduced to nearly zero by prompt therapy. ${ }^{244}$

Melioidosis, endemic in Australia, Southeast Asia and nearby islands, ${ }^{245}$ has a spectrum of severity ranging from inapparent to fatal disease. It appears as pneumonia, septicemia, localizes in joints, skin, liver, and bones and may become chronic. The death-rate is not so high as believed. A survey disclosed specific antibody in $15 \%$ of natives. Eight deaths occurred among thirty-five American victims who were or had been in Vietnam. ${ }^{246}$ Nine had mild pneumonia. As in tuberculosis or histoplasmosis, transient cavitation may ensue. ${ }^{247}$ Therapy was recommended with dangerously high dosage of kananmycin, chloramphenicol and novobiocin. ${ }^{248}$

Brucellosis (Mediterranean Fever) affects $20 \%$ of bisons in Yellowstone Park. ${ }^{249}$

$\mathrm{L}$ forms of $\boldsymbol{H}$. influenza were present in sputum of patients treated with pencillin. When treatment was stopped, $L$ forms reverted to the usual bacillary forms. ${ }^{250}$

\section{Coccal infections}

\section{Streptococci}

Among 4000 victims of scarlet fever, 171 had second attacks during a 4-year period. Reinfection presumably depended on the kind of penicillin administered during the first attack. ${ }^{251}$ An anti-streptococcal vaccine is under trial, but if scarlet fever leaves transient immunity, what can be expected of a vaccine? As yet, no coccal infection can be prevented by vaccination. Identification of streptococci made from throat cultures in physicians' private offices often is faulty. ${ }^{252}$

Hemolytic streptococci caused ninety-five cases of pneumonia among recruits, without preceding viral respiratory tract infections. Empyema, pericarditis and abscesses occurred. Nephritis ensued in one case, but rheumatic fever was not observed. ${ }^{253}$ In a community, a second epidemic of acute nephritis caused by type-49 streptococci recurred after 17 years. ${ }^{254}$ After many previously unsuccessful attempts, acute glomerulonephritis 
similar to that in man was induced by inoculating rabbits with a nephritogenic strain of streptococci. ${ }^{25}$ An immunosuppressant component of Group A streptococci was discovered.256

\section{Staphylococci}

Tests of antimicrobic sensitivity on 442 strains of staphylococci obtained from children not in hospitals disclosed high-resistance to penicillin in $90 \%$. The majority also resisted bacitracin, tetracycline, kanamycin and streptomycin. Evidently antimicrobic-resistant staphylococci are not confined to hospitals. ${ }^{257}$ 'Toxic epidermal necrosis' may be caused by a unique toxic effect of staphylococcus type 71.258

The death-rate from pneumococcal meningitis ranges between $10 \%$ and $65 \%$. The presence of associated disease is of graver import than advanced age.259 Pneumococcal bacteremia caused a self-limiting febrile disease in three infants. ${ }^{260} \mathrm{Six}$ instances of pneumococcal peritonitis occurred in patients with postnecrotic cirrhosis. $^{261}$

Meningococcosis has a range of severity varying from mild to fatal disease. During a study of 112 cases, the death rate was $7 \%$. Adrenal insufficiency plays no role in accompanying shock. Corticosteroids were of no value in treatment. Penicillin is the drug of choice for therapy. Ampicillin, tetracycline, erythromycin and cephalothin also are effective. No single antimicrobic nor combination is satisfactory for mass prophylaxis or for treating carriers. Early diagnosis and treatment are more effective. ${ }^{262}$

\section{Pneumonias}

Three papers on pneumonia appeared in the December 1967 issue of the American Review of Respiratory Disease. Pseudomonal pneumonia, as described in seven patients with severe predisposing disease, is a distinct entity. It was characterized by firm necrotic lesions with many bacilli and monocytic cell predominance, but minimal inflammation. Features of pneumonias caused by Proteus, Pseudomonas and Bacteroides were described in three respective papers in the February issue of the Annals of Internal Medicine. In most instances, the infections occurred in debilitated patients. Information of Pneumocystis carinii pneumonia was reviewed. No distinctive roentgenographic shadows distinguish viral pneumonias from those caused by Mycoplasma. Psittacosis is easily confused with bacterial pneumonias. Pericarditis, arthritis and hepatitis occur. ${ }^{263}$

\section{Endocarditis}

An editorial called attention to the changing nature and increased incidence of endocarditis in old age, during other chronic diseases and after cardiac surgery. It often is caused by penicillinresistant staphylococci, enterococci and occasionally by Brucella, Candida, Histoplasma, Coxiella and others. Although penicillin given prophylactically to 'cover' exodontia or tonsillectomy may be important, long-term antimicrobic therapy favors the replacement of sensitive streptococci by resistant microbes. Against general advice to use bactericidal agents, sulfonamides instead were recommended for prophylaxis against rheumatic fever since they suppress infection with hemolytic streptococci without suppressing the less sensitive Str. viridans in the mouth. ${ }^{284}$ The incidence of bacterial endocarditis in rheumatic children who received prophylactic antimicrobics was about the same as in the pre-antimicrobic era. Evidently, therapy did not increase the risk. ${ }^{265}$ Penicillin-, ampicillin- and cephaloridine-resistant Streptococcus viridans was present in the saliva of children who had received penicillin. ${ }^{266}$

Surgical replacement of infected cardiac valves during subacute bacterial endocarditis was performed in three patients. The procedure was recommended when antimicrobic therapy fails and for intractable cardiac failure. ${ }^{267}$ Combined cephalothin and streptomycin were not superior to penicillin for treating enterococcal endocarditis. ${ }^{268}$ Penicillin alone or with streptomycin is the drug of choice, but seventy-one $(18 \%)$ of 400 patients were sensitive to penicillin. Urgency in fifty-six of these required administration of penicillin and twenty-two had an allergic reaction in contrast to three who previously had had no reaction. As a rule, unless survival is dubious, nonpenicillin agents should be used. ${ }^{269}$

Rare instances of endocarditis caused by an Actinobacillus, 270 by a chromogenic mycobacterium, ${ }^{270 a}$ and by $H$. capsulatum ${ }^{271}$ were observed. Reports of endocarditis caused by Moraxella, ${ }^{272}$ and others caused by Esch. coli and Salmonella appeared in the October 1967 issue of Archives of Internal Medicine.

A second victim of $C$. neoformans endocarditis was cured by treatment with amphotericin B for 35 days. No evidence of nephrotoxity nor recurrence of infection followed. ${ }^{273} \mathrm{~A}$ murine adenovirus caused endocarditis in inoculated mice similar to that caused by Coxsackie $\mathbf{A}_{4}$ virus. Adenovirons and inclusion bodies were visualized in nuclei of endothelial cells. ${ }^{274}$

Twenty-nine of fifty hearts of children examined post mortem had interstitial myocarditis. Coxsackie virus $B$ antigen present in twelve suggested a causal relation. Probably cases previously named idiopathic myocarditis now 
can be specifically diagnosed. The lesion may be a cause of sudden death of infants. ${ }^{275}$

\section{Venereal infections}

\section{Gonorrhea}

Because of its increasing incidence, gonorrhea was said to be out of control and excepting colds, is the most prevalent infectious disease in the United States. An estimated 3-4 million infections occur annually but less than $10 \%$ are reported officially. ${ }^{276}$ In New York City the rate among teenage persons has increased $264 \%$ since 1955 , and $9 \%$ more than last year. ${ }^{277}$ Gonorrheal pharyngitis was described for the first time. ${ }^{278}$

In Canada, $27 \%$ of gonococcal strains isolated from patients had developed resistance to penicillin, some of them to $1.0 \mathrm{unit} / \mathrm{ml} .^{279}$ Cephalosporin may be a substitute for therapy. In different areas of the United States, the percentage of penicillin-resistant strains increased from $11 \%$ in 1962 to $60 \%$ in $1966 .{ }^{280}$

Three articles about treating gonorrhea among military personnel appeared in the 6 November 1967 issue of Journal of the American Medical Association. In naval service, failure followed therapy with penicillin in $29 \%$ of cases, whereas tetracycline was 'always' successful. Postgonococcal urethritis affected about two-thirds of the patients, but less often after tetracycline had been given. Mycoplasma often was the cause. Tetracycline was said to be effective in treating nongonococcal urethritis.

Nearly $90 \%$ of cases of gonorrhea and syphilis are not reported to public health authorities by private physicians. Physicians usually were unwilling to do so lest the patients be embarrassed. Hence source and contact are undetected and infection continues to be spread. ${ }^{281}$ The availability of antimicrobics and recently of contraconceptive medication was said to favor promiscuity and contribute to the increased incidence of venereal diseases.

Spirochetes, demonstrated by immunofluorescence, were present without evidence of abnormalities in the liver, aqueous humor and spinal fluids of patients with late seronegative syphilis. ${ }^{282}$ Motile spirochetes resembling Tr. pallidum were present in the aqueous humor of patients who had had syphilis years before and apparently had been adequately treated. ${ }^{273}$

A vaccine against syphilis is under investigation. ${ }^{284}$ So far, vaccines have been successful in preventing some viral infections, less so for rickettsioses and one or two bacillary diseases, and least or not at all against cocci or fungi. It will be surprising if treponemal, protozoal or mycotic infections can be prevented by vaccination.
Other infections

\section{Malaria}

Falciparum malaria in Vietnam is characterized by high fever, headache, myalgia, gastrointestinal and pulmonic involvement. Recrudescences ensued in $95 \%$ of victims after therapy with chloroquine or quinine alone or in combination. Pyrimethamine gave better results, but the best were achieved with sulfadiazine and diaminodiphenylsulfone. ${ }^{285}$ In other studies, colchicine-quinine reduced the recurrence rate. ${ }^{286}$ About $1.6 \%$ of 1200 patients with malaria developed the cerebral form. With proper therapy, all recovered without residual harm.287 Malaria must be suspected in febrile illnesses in south-east Asia and northern South America. ${ }^{288}$

Most military personnel who developed malaria on return from Vietnam, did so after several weeks. In $83 \%$ of cases, $P$. vivax was the cause. ${ }^{289}$ Recent progress and problems of malaria were reviewed by Neva. Control is possible but eradication still is a distant goal. ${ }^{290}$

\section{Mycoses}

\section{Histoplasmosis}

The ecology of histoplasmosis was discussed Podzolic soil, bird manure, proper conditions a temperature, humidity, and winds are necessar for the existence of $H$. capsulatum in nature? The highest incidence of disease and deaths occurs in age groups less than 1 year and between 46 and 64 years. ${ }^{291}$ Thirteen of seventeen bats in Alabama harbored $H$. capsulatum. Guano collectors, speleologists and cleaners of avian roots are at risk. ${ }^{292}$ In 1963, histoplasmosis was observed in 147 patients with nine deaths in Montreal. Many undiagnosed mild infections probably occurred. The source seemed to be in soil at a bird-roost. ${ }^{293}$ In different regions of Colombia, South America, from zero to $74 \%$ of the population reacted to the histoplasmin skin test. ${ }^{294}$ Lingual ulceration was observed in a patient with disseminated histoplasmosis. The lesion disappeared after administration of amphotericin in a total amount of $2530 \mathrm{mg}$ for 5 months. ${ }^{295}$ Histoplasmosis presumably caused choroiditis in 190 patients. ${ }^{296}$

Asymptomatic or inapparent cryptococcal infection is not uncommon and often results from the inhalation of dust especially in areas occupied by pigeons. The dermal test with cryptococcin gave positive results in $32 \%$ of pigeons fanciers, and $4 \%$ of others. ${ }^{297}$ Candidemia without evidence of actual infection needs no therapy except to remove resistanceimpairing factors if possible. If invasion and ill- 
ness occur or if iatrogenic factors exist, therapy with amphotericin is needed.298

Only eight of 160 patients with cephalic mucormycosis survived. Most victims had been debilitated previously and $42 \%$ were diabetic. ${ }^{299}$ Maddy reviewed the epidemiology and ecology of deep mycoses of man and animals. ${ }^{300}$

\section{Nosocomial infections}

Reports about nosocomial and iatrogenic infections emphasize the growing importance of the problem often resulting from mismanagement, but also from the unavoidable use of resistancesuppressant agents and procedures. In one hospital, septicemia with Gram-negative bacilli increased six-fold after the 'golden age' of antimicrobic therapy ended in 1955.301 Immunosuppressive therapy has increased the incidence of infections with Pneumocystis carinii. ${ }^{302}$ Six patients with underlying disease who received immunosuppressive drugs had Pn. carinii pneumonia. Diagnosis was made antemortem in only one instance by pulmonic biopsy. Treatment with pentamidine seemed to be therapeutically effective. ${ }^{303}$ 303a $^{30}$ Pseudomonas is a hazard in surgical practice. ${ }^{304}$ Gram-negative bacillemia, staphylococcal and fungal infections were major causes of death in leukemic patients. The incidence of infection increases in proportion to the duration of leukemia and the use of therapeutic agents. ${ }^{303}$

Gram-negative bacilli have replaced staphylococci as causes of hospital-acquired infections particularly of the respiratory and urinary tracts. In one hospital, Gram-negative bacilli accounted for two-thirds of cases. ${ }^{306}$ Elsewhere, eighty-two cases of pneumonia caused by Klebsiella-enterobacter, Esch. coli, Pseudomonas, Bacteroids, Proteus, $\boldsymbol{H}$. influenza and Achromobacter accounted for $4 \%$ of all pneumonias in 30 months. Esch. coli infection in twenty victims, mostly chronically ill and more than 50 years old, gave a deathrate of $60 \%$. Kanamycin was the therapeutic agent of choice.307 Nine of sixteen debilitated patients with Serratia marcescens septicemia died. ${ }^{308}$ Kanamycin at present is the drug of choice for treatment. Listeria monocytogenes caused bacteremia or meningitis in sixteen patients with lymphomas. Antimicrobics inhibited the bacilli in vitro, but had little or no therapeutic effect. ${ }^{309}$ Systemic mycosis involved twenty-three of fifty-seven patients who had had renal transplantation and immunosuppressive therapy. ${ }^{310}$ Among ninety-six heroin addicts, forty-two had hepatitis ; twenty-one, cellulitis or thrombophlebitis ; seventeen, pneumonia, eight had endocarditis and one had tetanus. ${ }^{311}$ Nine of eleven others with pulmonic infections had septicemia and two died. ${ }^{312}$

About one in 1500 patients died from nosocomial infections in a hospital. ${ }^{313}$ Postoperative 'Gram-negative' shock occurred eighteen times often in diabetic patients than in others. ${ }^{314}$ A prosthetic device replacing the aortic valve was the nidus of infection with Histoplasma capsulatum..$^{315}$

\section{Miscellaneous items}

According to Freeman, about $80 \%$ of patients with chronic urinary tract infection have relapses after apparently successful antimicrobic treatment. In a 13-month period relapse occurred in only $21 \%$ who were given methenamine mandelate continuously. In those who received nitrofurantoin or sulfamethizole, 42 and $55 \%$ had recurrences, and $87 \%$ in placebo-treated patients. Esch. coli, Klebsiella, Aerobacter and Pseudomonas were implicated. Mixed infection was present in $15 \% .^{316}$ Urine often inhibits growth or is bactericidal for Esch. coli and other Gram-negative bacilli, for enterococcus and Staph. albus. ${ }^{317}$

Toxoplasmosis was acquired by thirty-eight adult patients, and the parasite was isolated from the lymph nodes of ten. Lymphadenopathy, fever and malaise were the chief features, but myocarditis, encephalitis and chorioretinitis occurred. The disease usually is self-limiting. ${ }^{318}$ A pathologist acquired toxoplasmosis at necropsy on a patient with underlying Hodgkin's disease. ${ }^{319}$

Protoplasts of Str. fecalis, Str. pyogenes and Esch. coli were killed by serum while their bacterial forms were resistant. In contrast, protoplasts of $\boldsymbol{P}$. mirabilis resisted serum, but the bacterial forms did not. ${ }^{320}$

Accidental inoculation, tick bites and possibly airborne transmission caused Rocky Mountain spotted fever in five laboratory workers in an 11-year period. Four had been vaccinated previously. ${ }^{321}$ Since 1950,2700 cases of laboratoryacquired infections and 107 deaths were recorded. Arbo viruses accounted for 428 cases and sixteen deaths. ${ }^{322}$

Squirrels infected with L. grippotyphosa were the source of leptospirosis in four persons. ${ }^{323}$ Electron-microscopy disclosed what appeared to be pathogenic spirochetes invading colonic mucosa. ${ }^{324}$ Similar observations suggested that some microbes enter the mucosa without causing harm. ${ }^{325}$ Schistosome cercarias penetrated the skin of mice but failed to develop into adult worms if 14, 15-epoxygeranylgeranoil had been applied prophylactically. ${ }^{326}$ Filtration removed hundreds of schistosome flukes from the blood 
of patients after their dislodgement from the liver with antimony tartrate. ${ }^{327}$ Thiabendazole seemed to cure severe infection with strongyloides. ${ }^{328}$

Among 100 febrile American servicemen in South Vietnam, diagnosis was achieved in seventy-four. Dengue, chickungungya infection, scrub typhus and falciparum malaria predominated. Melioidosis, leptospirosis, cholera and plague were not encountered in the group observed. $329,329 a$

Serologic evidence of infection with a variety of microbes pathogenic for man was found in fish from polluted waters. ${ }^{330}$ Filamentous bacteria grew at temperature of $91.5^{\circ} \mathrm{C}$ in hot springs in Yellowstone Park. The upper limit of temperature at which microbes survive and grow is unknown. ${ }^{331}$

\section{References}

1. Fraud charged to Pfizer in tetracycline patent. Hosp. Tribune, 23 October 1967.

2. Hewit, W.L. (1967) Penicillin-historical impact on infection control. Ann. N.Y. Acad Sci. 145, 212.

3. BORDA, I. et al. (1967) Studies of drug usage in five Boston hospitals. J. Amer. med. Ass. 202, 506.

4. Editorial (1967) Cross-allergenicity of penicillins and cephalosporins. J. Amer. med. Ass. 199, 495.

5. Stewart, G.T. (1967) Allergenic residues in penicillin. Lancet, i, 1177.

5a. KNUdSEN, E.T. et al. (1967) Lancet, i, 1184.

6. Altemeier, W.A. (1967) Bodily response to infectious agents. J. Amer. med. Ass. 202, 1085.

7. TRUANT, J.P. (1967) Three-year survey of antibacterial spectra of the more commonly used chemotherapeutic agents. Canad. med. Ass. J. 96, 589.

8. Ampicillin (1967) The Medical Letter on Drugs and Therapeutics, 9, 78.

9. BUlgER, R.J. (1967) A methicillin-resistant strain of staphylococcus aureus. Clinical and laboratory experience. Ann. intern. Med. 67, 81.

10. Kenel, R. et al. (1967) Typhoid fever epidemic in schoolchildren. Schweiz. med. Wschr. 97, 875.

11. BenNer, E.J. \& MoRthland, V. (1967) Methicillin resistant staphylococcus aureus. Antibicrobial susceptibility. New Engl. J. Med. 277, 698.

12. Comparative assessment of the broad-spectrum penicillins and other antibiotics (1967). Ann. N.Y. Acad. Sci. 144, 207.

13. Gorini, L., Rosset, R. \& Zimmerman, R.A. (1967) Phenotypic masking and streptomycin dependence. Science, 157, 1314.

14. BULGER, R.J. (1967) In vitro effectiveness of kanamycin and kanamycin/cephalothin against Klebsiella. Ann. intern. Med. 67, 523.

15. Kanamycin and Neomycin (1967) The Medical Letter on Drugs and Therapeutics, 9, 61.

16. Davis, C.M., Fulghum, D.D. \& Taplin, D. (1968) The value of neomycin in neomycin-steroid cream. J. Amer. med. Ass. 203, 298.

17. PhIllips, I. et al. (1968) Acetic acid in the treatment of superficial wounds infected by Pseudomonas aeruginosa. Lancet, $\mathrm{i}, 11$.

18. Medeiros, A.A. \& O'Brien, T.F. (1967) Patterns of infectious drug resistance in a general hospital. Abstracted, Ann. intern. Med. 66, 1047.
19. Salzman, T.C. (1967) Transferable drug resistance ( $R$ Factor) in enteric bacteria: Relationship to nosocomial infections. Abstracted, Ann. intern. Med. 66, 1048.

20. Collentine, G.E., Waisbren, B.A. \& Mellender, J.W. (1967) Treatment of burns with intensive antibiotic therapy and exposure. J. Amer. med. Ass. 200, 939.

21. Meade, R.H. \& Weinstein, L. (1967) Discussion in Panel on Infectious Disease, No. 3. Eli Lilly, Indianapolis.

22. Herter, P. \& Slanetz, C.A. (1967) Influence of antibiotic preparation of the bowel on complications after colon resection. Amer. J. Surg. 165.

23. GouLd, L. (1967) Penicillin prophylaxis: cardiac catheterization. J. Amer. med. Ass. 202, 662.

24. Goodman, J.S. et al. (1968) Infection following cardiovascular surgery. New Engl. J. Med. 278, 117.

24a. Editorial (1968) Prophylactic antibiotics and heart surgery. New Engl. J. Med. 278, 162.

25. Goslings, W.R.O. et al. (1967) Continuous suppressive antimicrobial treatment in chronic infected bronchitis during the winter months. Dis. Chest. 52, 376.

26. Tempest, B. \& Austrian, R. (1967) Cephaloridine and penicillin $G$ in the treatment of pneumococcal pneumonia. Ann. intern. Med. 66, 1109.

27. Kaplan, K., Reisberg, B.E. \& Weinstein, L. (1967) Cephaloridine: antimicrobial activity and pharmacologic behavior. Amer. J. med. Sci. 253, 667.

28. Cephaloridine (1967) Postgrad. Med. J. 43, Supp. (August) 9-174.

29. Sutherland, R. \& Robinson, O.P.W. (1967) Laboratory and pharmacological studies in man with hetacilling and ampicillin. Brit. med. J. i, 804.

30. Brumfitt, W., Percival, A. \& Leigh, D.A. (1967) Clinical and laboratory studies with carbenicillin. $A$ new penicillin active against pseudomonas. Lancet, $i$, 1289.

31. Macfarlane, J.A. et al. (1968) Spiramycin in the prevention of post-operative staphylococcal infection. Lancet, $\mathbf{i}, 1$.

32. Saslaw, S. \& Carlisle, H.N. (1967) Studies on therapy of staphylococcal infections in monkeys. I. Comparison of cloxacillin, triacetyloleandomycin and erythromycin. Proc. Soc. exp. Biol. (N.Y.) 125, 1168.

33. Gottleieb, D. \& Shaw, P.D. (eds) (1967) Antibiotics, Vol. 1. Springer-Verlag, New York.

34. Smith, H., LeRner, P.I. \& Weinstein, L. (1967) Nontoxicity and 'massive' intravenous therapy with penicillin. Arch. intern. Med. 120, 47.

35. BloOmer, H.A., Barton, L.J. \& MADDOCK, R.K. (1967) Penicillin-induced encephalopathy in uremic patients. J. Amer. med. Ass. 200, 121.

36. CoHIll, D.F. et al. (1967) Central nervous system toxicity secondary to massive doses of penicillin ' $G$ ' in the treatment of overwhelming infections. Amer. J. med. Sci. 254, 692.

37. TOMPSETT, R. (1967) Pseudoanaphylactic reactions to procaine penicillin G. Arch. intern. Med. 120, 505.

38. Fellner, M.J., Ball, E.H. \& BaER, R.L. (1967) 'Double reaction' to penicillin. Arch. Derm. 96, 687.

39. Brauninger, G.E. \& Remington, J.S. (1968) Nephropathy associated with methicillin therapy. J. Amer. med. Ass. 203, 103.

40. BEIRNE, G.J. et al. (1967) Acute renal failure caused by hypersensitivity to polymyxin B sulfate. J. Amer. med. Ass. 201, 62.

41. Randall, R.E. (1967) Renal failure following antibiotics. Abstracted, Ann. intern. Med. 66, 1052. 
42. Kunin, C.M. (1967) Nephrotoxicity of Antibiotics. J. Amer. med. Ass. 202, 204.

42a. KunIN, C.M. (1967) A guide to use of antibiotics in patients with renal disease. Ann. intern. Med. 67, 151.

43. Peters, R.L. et al. (1967) Tetracycline-induced fatty liver in non-pregnant patients: A report of six cases. Amer. J. Surg. 113, 622.

44. Schwindt, W.D. \& Kisken, W. (1967) Postoperative hemorrhage and the tetracyclines. Amer.J. Surg. 113, 837.

45. FEKETE, F.R. (1968) Gastrointestinal complication of antibiotic therapy. J. Amer. med. Ass. 203, 210.

46. Strauss, W.J. \& Griffin, L.M. (1967) Nitrofurantoin pneumonia. J. Amer. med. Ass. 199, 265.

47. BEST, W.R. (1967) Chloramphenicol-associated blood dyscrasias. J. Amer. med. Ass. 201, 181.

48. Molthan, L., Reidenberg, M.M. \& Eichman, M.F. (1967) Positive direct Coombs tests due to cephalothin. New Engl. J. Med. 277, 123.

49. Sheiman, L., Spielvogel, A.R. \& Horowitz, H.I. (1968) Thromobocytopenia caused by cephalothin sodium. J. Amer. med. Ass. 203, 601.

50. Tinne, J.E., Gordon, A.M., Bain, W.H. \& Mackey, W.A. (1967) Cross-infection by Pseudomonas aeruginosa as a hazard of intensive surgery. Brit. med.J. vi, 313.

51. Espiritu, C.R., KIM, T.S. \& Levine, R.A. (1967) Granulomatous hepatitis associated with sulfadimethoxine hypersensitivity. J. Amer. med. Ass. 202, 985.

52. Eisenstadt, H.B. (1967) A case of hiccups. J. Amer. med. Ass. 202, 915.

53. Lederer, F.L. (1967) The price of progress. Amer. J. med. Sci. 254, 744.

54. Seelig, M.S. (1966) The role of antibiotics in the pathogenesis of Candida infections. Amer.J. Med. 40, 887.

55. Pullen, H., Wright, N. \& Murdock, J.M. (1967) Hypersensitive reactions to antibacterial drugs in infectious mononucleosis. Lancet, ii, 1176.

56. Glezen, W.P. et al. (1967) Group A streptococci, mycoplasmas and viruses associated with acute pharyngitis. J. Amer. med. Ass. 202, 455.

57. LodA, F.A. et al. (1968) Studies of the role of viruses, bacteria and $M$. pneumoniae as causes of lower respiratory tract infections in children. J. Pediat. 72, 161.

58. Nichol, K.P. \& CherRy, J.D. (1967) Bacterial-viral interrelations in respiratory infections of children. New Engl. J. Med. 277, 667.

59. Artenstein, M.S. et al. (1967) Acute respiratory' disease and meningococcal infection in army recruits. J. Amer. med. Ass. 201, 1004.

60. Kilbourne, E.D. (1967) Respiratory disease outbreaks. Arch. environm. Hlth, 14, 768.

61. Cold Doesn't Affect the 'Common cold' in study of rhinovirus infections. J. Amer. med. Ass. 199, Med. News, p. 29.

62. Mascoli C.C. et al. (1967) Rhinovirus infection in nursery and kindergarten children. New rhinovirus serotype 54. Proc. Soc. exp. Biol. (N.Y.), 124, 845.

63. Cherry, J.D., Diddams, J.A. \& Dick, E.C. (1967) Rhinovirus disease in hospitalized children. Arch. environm. Hlth, 14, 380.

64. Gwaltney, J.N. et al. (1967) Rhinovirus infection in an industrial population. J. Amer. med. Ass. 202, 494.

65. CATE, T.R. et al. (1967) Studies on the inability of rhinovirus to survive and replicate in the intestinal tract of volunteers. Proc. Soc. exp. Biol. (N.Y.) 124, 1290.

66. Stenhouse, A.C. (1967) Rhinovirus infection in acute exacerbations of chronic bronchitis: A controlled prospective study. Brit. med. J. iii, 461 .
67. Osler, W. (1892) The Principles and Practice of Medicine, 1st edn, p. 474. Appleton, New York.

68. GARDNER, P.S. et al. (1967) Deaths associated with respiratory tract infection in childhood. Brit. med. $J$. iv, 316.

69. MAYNARD, J.E. et al. (1967) Surveillance of respiratory virus infection among Alaskan Eskimo children. J. Amer. med. Ass. 200, 927.

70. Influenza Epidemic at a Dental School (1967) InfluenzaRespiratory Diseases Surveillance. V.X. Dept. Health, Education and Welfare. Report No. 83, June 30, 1967.

71. The Amantadine Controversy (1967) Council on Drugs. J. Amer. med. Ass. 201, 372.

71a. The Amantadine Controversy (1967) Evaluation of a new antiviral agent. Amantadine hydrochloride (Symmetrel). J. Amer. med. Ass. 201, 374.

72. SABIN, A.B. (1967) Amantadine hydrochloride. Analysis of data related to its proposed use for prevention of A2 influenza virus disease in human beings. J. Amer. med. Ass. 200, 943.

73. Mclean, D.M., Bannatyne, R.M. \& Givan, K.F. (1967) Myxovirus dissemination by air. Canad. Med. Ass. J. 96, 1449.

74. DoAne, F.W. et al. (1967) Rapid laboratory diagnosis of paramyxovirus infections by electron microscopy. Lancet, ii, 751.

75. Levin, S., Dietrich, J. \& Guillory, J. (1967) Fatal nonbacterial pneumonia associated with adenovirus Type 4. Occurrence in an adult. J. Amer. med. Ass. 201, 975.

76. Tillotson, J.R. \& Lerner, A.M. (1967) Reovirus Type 3 associated with fatal penumonia. New Engl.J. Med. 276, 1060.

77. Nahmias, A.J., Griffith, D. \& Snitzer, J. (1967) Fatal pneumonia associated with adenovirus Type 7. Amer. J. Dis. Child. 114, 37.

78. JAFFe, B.F. \& MaASAB, H.F. (1967) Sudden deafness associated with adenovirus infection. New Engl. J. Med. 276, 1406.

79. McINTOSH, K. (1967) Recovery in tracheal organ cultures of novel viruses from patients with respiratory disease. Proc. Nat. Acad. Sci. 57, 933.

80. Schieble, J.H., Fox, B.L. \& Lennette, E.H. (1967) A probable new human picoravirus associated with respiratory disease. Amer. J. Epidem. 85, 297.

81. Armstrong, J.A. \& Pereira, M.S. (1967) Identification of 'Ryan Virus' as an amoeba of the genus Hartmannella. Brit. med. J. i, 212.

82. Respiratory infection is traced to amoeba (1967) Med. Wld News, 8, 35.

83. Wang, S.S. \& Feldman, H.A. (1967) Isolation of Hartmannella species from human throats. New Engl. J. Med. 277, 1174

84. Bradburne, A.F., Bynoe, M.L. \& Tyrrell, D.A.J. (1967) Effects of a 'new' human respiratory virus in volunteers. Brit. med. J. iii, 767.

85. KIPPS, A. et al. (1967) Fatal disseminated primary herpesvirus infection in children. S. Afr. med.J. 41, 647.

86. BeCKeR, W.B., KipPS, A. \& MCKenzIE, D. (1968) Disseminated herpes simplex virus infection. Amer. $J$. Dis. Child. 115, 1.

87. HerrmanN, E.C. (1967) Experiences in laboratory diagnosis of herpes simplex, varicella-zoster, and vaccinia virus infections in routine medical practice. Mayo Clin. Proc. 42, 744.

88. Maclean, A. L. (1967) Spray keratitis. Trans. Amer. Acad. Ophth. Otolarung. 71, 330.

89. Klemola, E. et al. (1967) Further studies on cytomegalovirus mononucleosis in previously healthy individuals. Acta med. scand. 182, 311. 
90. Diseases caused by cytomegaloviruses. Leading article. Brit. med. J. i, 72.

91. NiedermanN, P.C. et al. (1968) Infectious mononucleosis. Clinical manifestations in relation to EB virus antibodies. J. Amer. med. Ass. 203, 205.

92. Peters, J.H. (1967) Heterophile reactive antigen in infectious mononucleosis. Science, 157, 1200.

93. Shelley, W.B. (1967) Herpes simplex virus as a cause of erythema multiforme. J. Amer. med. Ass. 201, 153.

94. Middlecamp, J.N., Reed, C.A. \& Patrizi, G. (1967) Placental transfer of herpes simplex virus in pregnant rabbits. Proc. Soc. Exp. Biol. (N.Y.), 125, 757.

95. Menser, M.A. et al. (1967) Persistence of virus in lens for three years after prenatal rubella. Lancet, ii, 387.

96. Glasgow, L.A. et al. (1967) Interferon and cytomegalovirus in vivo and in vitro. Proc. Soc. Exp. Biol. (N.Y.), 125, 843.

97. Dent, P.B. et al. (1968) Rubella-virus/leucocyte interaction and its role in the pathogenesis of the congenital rubella syndrome. Lancet, i, 291.

98. FabiYI, A., Gitnick, G.L. \& SeVer, J.L. (1967) Chronic rubella virus infection in the ferret puppy. Proc. Soc. exp. Biol. (N.Y.), 125, 766.

99. Brody, J.A., Henle, W. \& Koprowski, H. (eds.) (1967) Chronic infectious neuropathic agents (China) and other slow virus infections. Current Topics in Microbiology and Immunology, Vol. 40. SpringerVerlag, New York.

100. 'Minivirus' poses new mystery for Medicine (1967) Med. Wld News, 8, 34.

101. Harland, W.A., Adams, J.H. \& McSeveney, D. (1967) Herpes-simplex particles in acute necrotizing encephalitis. Lancet, ii, 581 .

102. Olson, L.C. et al. (1967) Herpesvirus infections of the human central nervous system. New Engl. J. Med. 277, 1271.

103. MaY, G., Dahn, R. \& Reuss, K. (1967) Demonstrations of herpes virus in encephalitis. Dtsch. Med. Wschr. 92, 794.

104. Bellanti, J.A. et al. (1968) Herpes simplex encephalitis: brain biopsy and treatment with 5-iodo-2'deoxyuridine. J. Pediat. 72, 266.

105. SoutherN, P.M. et al. (1967) Clinical features of epidemic St Louis encephalitis. Abstracted. Ann. intern. Med. 66, 1049.

106. Johnson, D.A. \& EgER, G.W. (1967) Myelitis associated with an echovirus. J. Amer. med. Ass. 201, 637.

107. AnNOTATION (1967) Tick-borne encephalitis Lancet, ii, 762.

108. Gavrilla, I., Iurasog, G. \& Luca, E. (1967) Rabies in man. Ann. Inst. Pasteur, 112, 504.

109. Rabies Prophylaxis (1967) Ann. intern. Med. 67, 159.

110. Tierkel, E.S. \& Sikes, R.K. (1967) Preexposure prophylaxis against rabies. J. Amer. med. Ass. 201, 911.

111. Shaw, C.M., Buchan, G.C. \& Carlson, C.B. (1967) Myxovirus as possible etiologic agent of subacute inclusion body encephalitis. New Engl. J. Med. 277, 511.

112. Johnson, R.T. \& Mims, C.A. (1968) Pathogenesis of viral infection of the nervous system. New Engl. J. Med. $278,84$.

113. Naegleria causes amebic encephalitis (1967) J. Amer. med. Ass. 202, Med. News, p. 29.

114. Neurotropic viral diseases surveillance. Poliomyelitis. U.S. Dept. Health, Education \& Welfare, Atlanta, Ga., July 31, 1967.

115. LiPSEY, A.L. \& Boland, R.P. (1967) The exfoliative source of abnormal cells in urine sediments of patients with measles. Amer. J. Dis. Child. 113, 677.

116. Adams, J.M. (1967) Measles antibodies in patients with multiple sclerosis. Neurology, 17, 707.
117. Myxovirus infections (1967) J. Amer. med. Ass. 200, Med. News, 25.

117a. 'Slow Virus' in Dawson's encephalitis (1967) J. Amer. med. Ass. 200, 27.

118. Just, M., Rieder, H.P. \& Ritzel, G. (1967) Measles antibody in serum of multiple sclerosis patients. Klin. Wschr. 45, 705.

119. Freeman, J.M. et al. (1967) Additional evidence of the relation between subacute inclusion-body encephalitis and measles virus. Lancet, ii, 129.

120. LeGG, N.J. (1967) Virus antibodies in subacute sclerosing panencephalitis: A study of 22 patients. Brit. med. J. ii, 350.

121. Measles virus and subacute sclerosing panencephalitis. (1968) Science, 159, 451.

122. ReED, D. et al. (1967) A mumps epidemic on St. George Island, Alaska. J. Amer. med. Ass. 199, 967.

123. Hilleman, M.R. et al. (1967) Live attenuated mumpsvirus vaccine. IV Protective efficacy as measured in a field evaluation. New Engl. J. Med. 276, 252.

124. WeIBEL, R.E.et al. (1968) Jeryl Lynn strain live attenuated mumps virus vaccine. J. Amer. med. Ass. 203, 14.

124a. Atkinson, J.E. \& Bass, H.N. (1968) Mumps orchitis in a three-year-old child. J. Amer. med. Ass. 203, 892.

125. Thomas, F.D., Perkins, R.L. \& Saslaw, S. (1968) Paralytic mumps infection in two sisters. Arch. intern. Med. 121, 45.

126. IllingwORTH, R.S. (1967) Fallacies in four fevers. Lancet, ii, 44.

127. NovaK, A. et al. (1967) A community-wide coxsackievirus A9 outbreak. J. Amer. med. Ass. 202, 862.

128. Coxsackie B5 virus infection during 1965 (1967) Brit. med. J. iv, 575.

129. KURz, H. et al. (1967) Cardiovascular manifestations of proven coxsackie infections. Abstracted, Ann. intern. Med. 66, 1047.

130. BurCH, G.E. (1967) Coxsackie B viral myocarditis and valvulitis identified in routine autopsy specimens by immunofluorescent techniques. Amer. Heart J. 74, 13.

131. ECKeRT, H.L. et al. (1967) Group B coxsackie virus infection in infants with acute lower respiratory disease. Pediatrics, 39, 526.

132. Czeizel, A. (1967) Coxsackie virus and congenital malformation. J. Amer. med. Ass. 201, 156.

133. Froeschle, J.E. et al. (1967) Hand, foot, and mouth disease. Coxsackie virus A16 in Atlanta. Amer. J. Dis. Child. 114, 278.

133a. Miller, G.D. \& Tindall, J.P. (1968) Hand-foot-andmouth disease. J. Amer. med. Ass. 203, 827.

134. IRVINE, D.H. et al. (1967) Outbreak of ECHO virus Type 30 in a general practice. Brit. med. J. iv, 774.

135. Monif, G.R.G., LeE, C.W. \& Hsiung, G.D. (1967) Isolated myocarditis with recovery of ECHO type 9 virus from the myocardium. New Engl. J. Med. 277, 1353.

136. BRUNELL, P.A. (1967) Varicella-zoster infections in pregnancy. J. Amer. med. Ass. 199, 315.

137. LI, F. \& Hanshaw, J.B. (1967) Cytomegalovirus infection among migrant children. Amer. J. Epidem. 86, 137.

138. Rifkind, D., Goodman, N. \& Hill, R.B. (1967) The clinical significance of cytomegalovirus infection in renal transplant recipients. Ann. intern. Med. 66, 1116.

139. Cytomegalovirus infection after renal allotransplantation (1967) J. Amer. med. Ass. 201, 725.

140. CANGIR, A. et al. (1967) Cytomegalovirus syndrome in children with leukemia, treatment with floxuridine. J. Amer. med. Ass. 201, 612.

141. Eisner, G., BoHM, H.O. \& Julich, E. (1967) Footand-mouth disease in human beings: Case report. Dtsch. med. Wschr. 92, 830. 
142. Annotation (1967) Foot-and-mouth disease Lancet, ii, 1187.

143. Fields, B.N. \& Hawkins, K. (1967) Human infection with the virus of vesicular stomatitis during an epizootic. New Engl.J. Med. 277, 989.

144. Smith, C.E.G. et al. (1967) Fatal human disease from vervet monkeys. Lancet, ii, 1119.

145. Siegert, R. et al. (1967) On the cause of a previously unknown human infection transmitted from monkeys. Dtsch. med. Wschr. 92, 2341.

146. Hanson, R.P. et al. (1967) Arbovirus infections of laboratory workers. Science, 158, 1283.

147. NefF, J.M. et al. (1967) Dengue fever in a Puerto Rican community. Amer. J. Epidem. 86162.

148. MYERS, R.M. \& CAREY, D.E. (1967) Concurrent isolation from a patient of two arboviruses, Chikungunya and Dengue Type 2. Science, 1571307.

149. CHILD, P.L. et al. (1967) Bolivian hemorrhagic fever: A pathologic description. Arch. Path. 83434.

150. CHOU, S.M. (1967) Myxovirus-like structure in a case of chronic polymyositis. Science, 1581453.

151. McKay, D.G. \& Margaretten, W. (1967) Disseminated intravascular coagulation in virus diseases. Arch. intern. Med. 120, 129.

152. Wadlington, W.B. \& Riley, H.D. (1968) Arthritis and hemolytic anemia following erythema infectiosum. J. Amer. med. Ass. 203, 473.

153. SMith, J.W. \& SANFORd, J.P. (1967) Viral arthritis. Ann. intern. Med. 67, 651.

154. Jensen, M.M. (1967) Viruses and kidney disease. Review, Amer. J. Med. 43, 897.

155. Singer, M.F. (1967) In vitro synthesis of DNA: A perspective on research. Science, 158, 1550.

156. Particles used to infect, kill human cancer cells in vitro (1967) J. Amer. med. Ass. 201, Med. News, p. 34.

157. TamakA, Y., Bell, W.R. \& Brindley, D. (1967) Pseudoviral inclusion bodies in acute leukemia. J. Nat. Cancer Inst. 38, 629.

158. Toshima, S. et al. (1967) Electron microscopic and cytogenetic studies of cells derived from Burkitt's lymphoma. Cancer Res. 27, 753.

159. HeNLE, W. et al. (1967) Herpes-type virus and chromosomal marker in normal leukocytes after growth with irradiated Burkitt cells. Science, 157, 1064.

160. Mitchell, J.R. et al. (1967) Isolation of a virus from Burkitt lymphoma cells. Lancet, i, 1358.

161. BRyAN, W.R. \& EndicotT, K.M. (1967) The problem of viral oncogenesis. Ann. intern. Med. 67, 453.

162. Progress Against Cancer (1967) A report by the National Advisory Cancer Council. U.S. Dept. Health, Education \& Welfare, pp. 18-65.

163. Rous, P. (1967) The challenge to man of the neoplastic cell. Science, 157, 24.

164. Leukemia-virus answer on the horizon (1967) J. Amer. med. Ass. 202, 29.

165. Attenuated smallpox vaccine tested (1967) J. Amer. med. Ass. 200, Med. News, p. 41.

166. MCGEE, A.R. (1967) Apparent antagonism of vaccinia and wart virus. Cancer, 330, 1647.

167. Allyn, B. \& WAldoRf, D.S. (1968) Treatment of verruca with vaccinia. J. Amer. med. Ass. 203, 807.

168. Lepow, M., Nankervis, G.A. \& Robbins, F.C. (1967) Immunity of school children two years after oral poliomyelitis vaccination. J. Amer. med. Ass. 201, 27.

169. Parrotr, R.H. (1968) Conference on vaccines against viral and rickettsial diseases. J. Pediat. 72, 134.

170. Measles vaccines (1967) Ann. intern. Med. 67, 1055.

171. Editorial (1967) Complications of vaccination. Brit. med. J. iv, 253.
172. LUM, G.S. et al. (1967) Vaccinia epidemic and epizootic in El Salvador. Amer.J.trop. Med. Hyg. 16, 333.

173. VAN ROOYEN, C.E. et al. (1967) Vaccinia gangrenosa and 1-methylistan 3-thiosemicarbazone (methisazone). Canad. med. Ass. J. 97, 160.

174. Editorial (1967) Reactions following vaccination for measles New Engl. J. Med. 277, 265.

175. Fulginiti, V.A. et al. (1967) Altered reactivity to measles virus. J. Amer. med. Ass. 202, 1075.

176. Alter, H.J., SCANLON, R.T. \& SCHECHTER, G.P. (1968) Thrombocytopenic purpura following vaccination with attenuated measles virus. Amer.J. Dis. Child. 115, 111.

177. Wilhelm, D.J. \& Paegle, R.D. (1967) Thrombocytopenic purpura and pneumonia following measles vaccination. Amer. J. Dis. Child. 113, 534.

178. I. Diop MAR, et al. (1967) Encephalitis following antiyellow fever vaccination. Ann. Pediat. (Paris), 43, 689.

179. BalduzzI, P. \& Glasgow, L.A. (1967) Paralytic poliomyelitis in a contact of a vaccinated child. New Engl. J. Med. 276, 797.

180. Swanson, P.D., Mcalister, R. \& Peterson, D.R. (1967) Poliomyelitis associated with Type 2 virus. J. Amer. med. Ass. 201, 771.

181. WALSH, J. (1967) Foot-and-mouth disease: Britain strives to curb epidemic. Science, 158, 1435.

182. Sharp, J.C.M. \& McDonald, S. (1967) Effects of rabies vaccine in man, Brit. med. $J$. ii, 20.

183. Wilson, Sir Graham S. (1967) The Hazards of Immunization. Oxford University Press, New York.

184. LEDERBERG, J. (1967) Dangers of programming cells. Science, 158, 313.

185. LAMPSON, G.P. et al. (1967) Inducers of interferon and host resistance, I. Double-stranded RNA from extracts of penicillin Funiculosum. Proc. nat. Acad. Sci. (Wash.), 58, 752.

186. Chany, C. \& Brailovsky, C. (1967) Stimulating interaction between viruses (stimulons). Proc. nat. Acad. Sci. (Wash.), 57, 87.

187. Merigan, T.C. (1967) Interferon's promise in clinical medicine. Fact or fancy. Editorial. Amer. J. Med. 43, 817.

188. Evans, A.S., Allen, V. \& Sveltman, S. (1967) Mycoplasma pneumoniae infections in University of Wisconsin students. Amer. Rev. resp. Dis. 96, 237.

189. Feizi, T. et al. (1967) Studies on an epidemic of respiratory disease caused by Mycoplasma pneumoniae. Brit. med. J. i, 457.

190. ANDREWS, C.E. et al. (1967) An epidemic of respiratory infection due to Mycoplasma pneumoniae in a civilian population. Amer. Rev. resp. Dis. 95, 972.

191. Maisel, J.C., Babbitt, L H \& John, T.J. (1967) Fatal Mycoplasma pneumoniae infection with isolation of organisms from lung. J. Amer. med. Ass. 202, 287.

192. CoRdero, L. et al. (1967) Primary atypical pneumonia : An epidemic caused by Mycoplasma pneumoniae. J. Pediat. 71, 1.

193. Glezen, W.P. et al. (1967) Significance of Mycoplasma infection in children with respiratory disease. Pediatrics, 39, 516.

194. Bolasanian, N. \& Robbins, F.C. (1967) Mycoplasma pneumoniae infection in families. New Engl. J. Med. $277,719$.

195. Tilles, J.G. et al. (1967) Acute otitis media in children. Serologic studies and attempts to isolate viruses and mycoplasmas from aspirated middle-ear fluids. New Engl. J. Med. 277, 613.

196. KATZ, H.I. et al. (1967) Stevens-Johnson syndrome. J. Amer. med. Ass. 199, 504.

197. JAO, R.L. \& Finland, M. (1967) Susceptibility of Mycoplasma pneumoniae to 21 antibiotics in vitro. Amer. J. Med. Sci. 253, 639. 
198. Smith, C.B., Friedenwald, W.T. \& Chanock, R.M. (1967) Shedding of Mycoplasma pneumoniae after tetracycline and erythromycin therapy. New Engl. J. Med. 276, 1172.

199. Smith, C.B., Friedenwald, W.T. \& Chanock, R.M. (1967) Inactivated Mycoplasma pneumoniae vaccine. J. Amer. med. Ass. 199, 353.

200. Kundsin, R.B., Driscoll, S.G. \& Ming, P.L. (1967) Strain of mycoplasma associated with human reproductive failure. Science, 157, 1573.

201. Mosley, J.W., Reinhardt, H.P. \& Hassler, F.R. (1967) Chimpanzee-associated hepatitis. J. Amer. med. Ass. 199, 695.

202. Cline, A.L., Mosley, J.W. \& Scovel, F.G. (1967) Viral hepatitis among American missionaries abroad. J. Amer. med. Ass. 199, 551.

202a. Frame, J.D. (1968) Hepatitis among missionaries in Ethiopia and Sudan. J. Amer. med. Ass. 203, 819.

203. KoFF, R.S. \& SEAR, H.S. (1967) Internal temperature of steamed clams. New Engl. J. Med. 276, 737

204. Ringertz, O. \& Letterberg, B. (1967) Serum hepatitis among Swedish track finders. New Engl. J. Med. 276, 540.

205. Rosenstein, B.J. (1967) Viral hepatitis in narcotic users. J. Amer. med. Ass. 199, 698.

206. ToGHILL, P.J. et al. (1967) Cytomegalovirus hepatitis in the adult. Lancet, i, 1357.

207. Vischer, T.L., Bernheim, C. \& Engelbrecht, E. (1967) Two cases of hepatitis due to toxoplasma gondii. Lancet, ii, 919.

208. Cross, G.F. \& Marmion, B.P. (1967) Cell culture and infectious hepatitis. Med. J. Aust. 2, 1214.

209. MYers, J.A. (1967) Eighty years after the first glimpse of the tubercle bacillus. Dis. Chest, 51, 500 .

210. Comstock, G.W., Ferebee, S.H. \& Hammes, L.M. (1967) A controlled trial of community-wide isoniazid prophylaxis in Alaska. Amer. Rev. resp. Dis. 95, 935.

211. STEAD, W.W. (1967) Pathogenesis of a first episode of chronic pulmonary tuberculosis in man: Recrudescence of residuals of the primary infection or exogenous infection? Amer. Rev. resp. Dis. 95, 729.

212. SMITH, D.T. (1967) Diagnostic and prognostic significance of the quantitative tuberculin tests. The influence of subclinical infection with atypical Mycobacteria. Ann. intern. Med. 67, 919.

213. Chemoprophylaxis for the prevention of tuberculosis (1967) Report of the ad hoc committee on chemoprophylaxis of the National Tuberculosis Assoc. Amer. Rev. resp. Dis. 96, 558.

214. Curry, F.J. (1967) Prophylactic effect of isoniazid in young tuberculin reactors. New Engl. J. Med. 277, 562.

215. Houk, V.N. et al. (1968) The eradication of tuberculosis infection by isoniazid chemoprophylaxis. Arch. environm. Hlth, 16, 46.

216. Mitchell, R.S. (1967) 'Second line' antituberculosis drugs. J. Amer. med. Ass. 201, 147.

217. Roberts, M., Sheppard, G.L. \& McCormick, R.C. (1967) Tuberculous meningitis after intrathecally administered methylprednisone acetate. J. Amer. med. Ass. 20, 894.

218. Brown, J.K.F., Stone, M.M. \& Sutherland, I. (1968) B.C.G. vaccination of children against leprosy in Uganda: Results at end of second follow-up. Brit. med. J. i, 24.

219. SMITH, D.T. (1967) The influence of subclinical infections with atypical mycobacteria on the diagnostic and prognostic significance of quantitative tuberculin tests. Abstracted, Ann. intern. Med. 66, 1048.

220. OCHs, C.W. (1967) Tuberculin conversion. J. Amer. med. Ass. 200, 1019.
221. HоввеY, G.L. et al. (1967) A study on pulmonary disease associated with mycobacteria other than Mycobacterium tuberculosis: Identification and characterization of the mycobacteria. Amer. Rev. resp. Dis. 95, 954.

222. Kestle, D.G., Aвbott, V.D. \& Kubica, G.P. (1967) Differential identification of mycobacteria. II. Sub- $\stackrel{\mathcal{C}}{\overparen{P}}$ groups of groups II and III (Runyon) with different 7 clinical significance. Amer. Rev. resp. Dis. 95, 1041.

223. AGER, E.A. et al. (1967) Two outbreaks of egg-borne salmonellosis and implications for their prevention. J. Amer. med. Ass. 199, 372.

223a. Collins, R.N. et al. (1968) Interstate outbreak of Salmonella newbrunswick infection traced to powdered $\omega$ milk. J. Amer. med. Ass. 203, 838.

224. HaN, T., SoKal, J.E. \& Neter, E. (1967) Salmonellosis in disseminated malignant diseases: A seven-year review (1959-1965). New Engl. J. Med. 276, 1045.

225. Hathout, S.E., El-Ghaffar, Y.A. \& AWNY, A.Y. (1967) Salmonellosis complicating schistosomiasis in Egypt. Amer. J. trop. Med. Hyg. 16, 462.

226. WATSON, K.C. (1967) Intravascular Salmonella typhi as a manifestation of the carrier state. Lancet, ii, 332.

227. Schmelzer, L.L. et al. (1967) Gastroenteritis from an orange juice preparation: II. Field and laboratory investigation. Arch. environm. Hlth, 15, 78.

228. Renteln, H.A. \& Hinman, A.R. (1967) A waterborne epidemic of gastroenteritis in Madera, California. Amer. J. Epidem. 86, 1.

229. CoHen, R. et al. (1967) Microbial intestinal flora in acute diarrheal disease. J. Amer. med. Ass. 201, 835.

230. Farrar, W.E. \& DekLe, L.C. (1967) Transferable antibiotic resistance associated with an outbreak of shigellosis. Ann. intern. Med. 67, 1208.

231. Moffet, H.L., Shulenberger, H.K. \& Burkholdek E.R. (1968) Epidemiology and etiology of severe infantile diarrhea. J. Pediat. 72, 1.

232. Brooksaler, F. \& Nelson, J.D. (1967) Pertussis. A reappraisal and report of 190 confirmed cases. Amer. J. Dis. Child. 114, 389.

233. Cherubin, C.E. (1967) Urban tetanus. Arch. environm Hlth, 14, 802.

234. Wiemers, K. \& Eyrich, K. (1967) Results of treatment in 222 cases of tetanus. Dtsch. med. Wschr. 92, 1298.

235. Goyal, R.R., Neogy, C.N. \& Mathur, G.P. (1967) A controlled trial of antiserum in the treatment of tetanus. Lancet, ii, 1371.

236. Patel, J.C. \& Goodluck, P.L. (1967) Serum therapy in neonatal tetanus. Amer. J. Dis. Child. 114, 131.

236a. Milledge, J.S. (1968) Hyperbaric oxygen therapy in tetanus. J. Amer. med. Ass. 203, 875.

237. EDSALL, G. et al. (1967) Excessive use of tetanus toxoid boosters. J. Amer. med. Ass. 201, 17.

238. Marshall, J.D., QuY, D.V. \& Gibson, F.L. (1967) Asymptomic pharyngeal plague infection in Vietnam. Amer. J. trop. Med. Hyg. 16, 5.

239. Cohen, R.J. (1967) Pneumonic plague in an untreated plague-vaccinated individual. J. Amer. med. Ass. 202, 365.

240. Martin, A.R. et al. (1967) Plague meningitis: Report of three cases in children and review of the problem. Pediatrics, 40, 610.

241. Assal, N., Blenden, D.C. \& Price, E.R. (1967) Epidemiologic study of human tularemia reported in Missouri, 1949-65. Publ. Hlth Rep. 82, 627.

242. New theory proposed on nature of cholera (1967) Med. Wld News, 8, 30.

243. Wallace, C.K. et al. (1967) Probable gallbladder infection in convalescent cholera patients. Lancet, $\mathbf{i}$, 865. 
244. Reimann, H.A., Chang, C.T. et al. (1946) Asiatic cholera. Clinical study and experimental therapy with streptomycin. Amer. J. trop. Dis. 26, 631.

245. Johnson, W.D. (1967) Melioidosis: Report of Four Cases from Torres Strait. Med. J. Aust. ii, 587.

246. Cooper, E.B. (1967) Melioidosis. J. Amer. med. Ass. $200,452$.

247. Spotnitz, M., Rudnitzky, J. \& Rambaud, J.J. (1967) Melioidosis pneumonitis. J. Amer. med. Ass. 202, 950.

248. Sheehy, T.W., Deller, J.J. \& Weber, D.R. (1967) Melioidosis. Ann. intern. Med. 67, 897.

249. AllaRd, W.A. (1967) Yellowstone wildlife in winter. Nat. Geogr. Mag. 132, 637.

250. LAPINSKY, E.M. \& FlakAS, E.D. (1967) Induction of $\mathrm{L}$ Forms of Hemophilus influenzae in culture and their demonstration in human bronchial secretions. J. Bact. 93, 1438.

251. DEUTSCH, J. (1967) Repeat infection with scarlet fever. Dtsch. med. Wschr. 92,797

252. Mondzac, A.M. (1967) Throat culture processing in the office-a warning. J. Amer. med. Ass. 200, 1132.

253. Basilieri, J.L., Bistrong, H.W. \& SPENCE, W.F. (1967) Streptococcal pneumonia: Recent outbreak in military recruit population. Abstracted, Ann. intern. Med. 66, 1045.

254. Anthony, B.R. et al. (1967) Epidemic of acute nephritis with reappearance of type-49 streptococcus. Lancet, ii, 787.

255. BeCKer, C.G. \& MurPhy, G.E. (1968) The experimental induction of glomerulonephritis like that in man by infection with Group A streptococci. J. exp. Med. 127, 1.

256. Malakian, A. \& Schwab, J.H. (1968) Immunosuppressant from Group A streptococci. Science, 159, 880.

257. Anthony, B.F., Giebink, G.S. \& Quie, P.G. (1967) Neomycin-resistant staphylococci in a rural outpatient population. Amer. J. dis. Child. 113, 664.

258. JEFFERSON, J. (1967) Lyell's toxic epidermal necrolysis: A staphylococcal etiology. Brit. med. J. i, 802.

259. Weiss, W. et al. (1967) Prognostic factors in pneumococcal meningitis. Arch. intern. Med. 120, 517.

260. Belsey, M. (1967) Pneumococcal bacteremia. Amer. J. dis. Child. 113, 588.

261. Epstein, M., Calia, F.M. \& Gabuzda, G.J. (1968) Pneumococcal peritonitis in patients with postnecrotic cirrhosis. New Engl. J. Med. 278, 69.

262. Wolf, R.E. \& BirbarA, C.A. (1968) Meningococcal infections at an Army training center. Amer. J. Med. 44, 243.

263. SChAFFner, W. et al. (1967) Clinical spectrum of endemic psittacosis. Arch. intern. Med. 119, 433.

264. Changing face of infective endocarditis (1967) Editorial Brit. med. J. i, 389.

265. Doyle, E.F. et al. (1967) The risk of bacterial endocarditis during antirheumatic prophylaxis. J. Amer. med. Ass. 201, 807.

266. STIRLAND, R.M. (1967) Antibiotic-resistant streptococci in the mouths of children treated with penicillin. Lancet, i, 405.

267. Wilcox, B.R. et al. (1967) Early surgical treatment of valvular endocarditis. J. Amer. med. Ass. 200, 820.

268. SimON, H.J. (1967) Antimicrobial susceptibility of Group D streptococci. Amer. J. med. Sci. 253, 14.

269. Green, G.R., Peters, G.A. \& GeraCI, J.E. (1967) Treatment of bacterial endocarditis in patients with penicillin hypersensitivity. Ann. intern. Med. 67, 235.

270. VogelzaNG, R.M. (1967) Bacterial endocarditis due to Actinobacillus actinomycetemcomitans. Arch. intern. Med. $102,99$. 270a. Geraci, J.E., Anderson, M.W. \& Karlson, A.G. (1968) Endocarditis due to a rapidly growing chromogenic mycobacterium. Mayo Clin. Proc. 43, 124.

271. Hartley, R.A., Remsberg, J.R.S. \& SinAly, N.P. (1967) Histoplasma endocarditis. Arch. intern. Med. $119,527$.

272. Christensen, C.E. \& Emmanouilides, G.C. (1967) Bacterial endocarditis due to 'Moraxella new species I'. New Engl. J. Med. 277, 803.

273. Colmers, R.A., Irniger, W. \& Steinberg, D.H. (1967) Cryptococcus neoformans endocarditis cured by amphotericin B. J. Amer. med. Ass. 199, 762.

274. Blailock, Z.R., Rabin, E.R. \& Melnick, J.L. (1967) Adenovirus endocarditis in mice. Science, 157, 69.

275. BURCH, G.E. et al. (1968) Interstitial and coxsackie B myocarditis in infants and children. J. Amer. med. Ass. 203, 1.

276. Gonorrhea 'out of control' (1967) J. Amer. med. Ass. News, 10, 12.

277. Soaring VD rates among teen-agers (1967) Med. Wld News, 8, 15.

278. Fiumara, N.J., Wise, H.M. \& MANY, M. (1967) Gonorrheal pharyngitis. New Engl. J. Med. 276, 1248.

279. AMIES, C.R. (1967) Development of resistance of gonococci to penicillin: An eight year study. Canad. med. Ass. J. 96, 33.

280. Gonorrhea: Resistance, cases grow (1967) J. Amer. med. Ass. 201, Med. News, p. 32.

281. Cleere, R.L. et al. (1967) Physicians' attitudes toward venereal disease reporting. J. Amer. med. Ass. 202, 941.

282. SMith, J.L. \& IsRaEL, C.W. (1967) The presence of spirochetes in late seronegative syphilis. J. Amer. med. Ass. 199, 980.

283. Syphilis-like agent found in eyes of patients after 'adequate' therapy (1968) J. Amer. med. Ass. 203, Med. News, p. 23.

284. Syphilis vaccine tests show promise (1967) J. Amer. med. Ass. 201, Med. News, p. 45.

285. Hunsicker, L.G., Schwartz, R.A. \& Barnwell, F.M. (1967) Malaria from Vietnam. Abstracted, Ann. intern. Med. 66, 1046.

286. Reba, R.C. \& Sheehy, T.W. (1967) Colchicinequinine therapy for acute falciparum malaria acquired in Vietnam. J. Amer. med. Ass. 201, 553.

287. DAROFF, R.B. et al. (1967) Cerebral malaria. J. Amer. med. Ass. 202, 679.

288. Blount, R.E. (1967) Chloroquinine resistant malaria, Editorial. J. Amer. med. Ass. 200, 886.

289. WATERHOUSE, B.E. \& RiggenbaCh, R.D. (1967) Malaria. Potential importance to civilian physicians. J. Amer. med. Ass. 202, 683.

290. NevA, F.A. (1967) Malaria-recent progress and problems. New Engl. J. Med. 277, 2141.

291. Addington, W.W. (1967) The ecology of histoplasmosis. Amer. J. med. Sci. 253, 687.

292. Ajello, L., Hosty, T.S. \& Palmer, J. (1967) Bat histoplasmosis in Alabama. Amer. J. trop. Med. Hyg. $16,329$.

293. BRANDT, J.L. et al. (1967) The epidemic of histoplasmosis in Montreal: Clinical experience in 147 cases, with results of a recent epidemiological study. Abstracted, Ann. intern. Med. 66, 1045.

294 TeSh, R.B. \& BenNetT, S.W. (1967) Histoplasmin sensitivity in Colombia. Amer. J. trop. Med. Hyg. 16, 752.

295. Hiley, P., HeilbrunN, C. \& Fields, J. (1967) Histoplasma ulcer of the tongue. J. Amer. med. Ass. 200, 1130.

296. Schlaegel, T.F. et al. (1967) Presumed histoplasmic choroiditis. Amer. J. Ophthal. 63, 919. 
297 NewberRy, W.M. et al. (1967) Epidemiologic study of Cryptococcus neoformans. Ann. intern. Med. 67, 724.

298. Ellis, C.A. \& SpIvaK, M.L. (1967) Significance of candidemia. Ann. intern. Med. 67, 511.

299. Prockop, L.D. \& Silva-Hutner, M. (1967) Cephalic mucormycosis (Phycomycosis). Arch. Neurol. 17, 379.

300. MADDY, K.T. (1967) Epidemiology and ecology of deep mycoses of man and animals. Arch. Derm. 96, 409.

301. Altemeier, W.A. (1967) Bodily response to infectious agents. J.. Amer. med. Ass. 202, 1085.

302. Vogel, C.L. et al. (1968) Pneumocystis carinii pneumonia. Ann. intern. Med. 68, 97.

303. Ruskin, J. \& Remington, J.S. (1967) The compromised host and infection. J. Amer. med. Ass. 202, 1070.

303a. Ruskin, J. \& Remington, J.S. (1967) Pneumocytis carinii pneumonia. J. Amer. med. Ass. 203, 604.

304. Tinne, J.E., Gordon, A.M., BaIn, W.H. \& Mackey, W.A. (1967) Cross infection by Pseudomonas aeruginosa as a hazard of intensive surgery. Brit. med. J. iv, 313.

305. Viola, M.V. (1967) Acute leukemia and infection. J. Amer. med. Ass. 201, 923.

306. McNamara, M.J. et al. (1967) A study of bacteriologic patterns of hospital infections. Ann. intern. Med. 66, 480.

307. Tillotson, J.R. \& Lerner, A.M. (1967) Characteristics of pneumonias caused by Escherichia coli. New Engl. J. Med. 277, 115.

308. DoBson, W.H. (1968) Serratia marcescens septicemia. Arch. intern. Med. 121, 151.

309. LouRIA, D.B. et al. (1967) Listeriosis complicating malignant disease. Ann. intern. Med. 67, 261.

310. RifKIND, D. et al. (1967) Systemic fungal infection complicating renal transplantation and immunosuppressive therapy. Amer. J. Med. 43, 28.

311. LouriA, D.B. (1967) Major medical complications of heroin addiction. Ann. intern. Med. 67, 1.

312. BRIGgS, J.H. et al. (1967) Severe systemic infection complicating 'mainline' heroin addiction. Lancet, ii, 1227.

313. THORBURN, R. et al. (1968) Infection acquired by hospitalized patients. An analysis of the overall problem. Arch. intern. Med. 121, 1.

314. ARIVAN, S. \& Halasz, N.A. (1967) Incidence of postoperative gram-negative shock in diabetics. Amer. $J$. med. Sci. 254, 808.
315. Weaver, D.R., Batsakis, J.G. \& Nishiyama, R.H. 气 (1968) Histoplasma endocarditis. Arch. Surg. 96, 158.

316. Therapy for urinary tract infection (1967) J.Amer. $\stackrel{\mathbb{D}}{\circ}$ med. Ass., Med News, 200, 31.

317. KAYE, D. (1967) Antibacterial activity of human urine, Program. Amer. Soc. clin. Invest. May 1, 1967, p. $58 \stackrel{\vec{\jmath}}{ }$ (Abstracted).

318. Jones, T.C., Kean, B.H. \& Kimball, A.C. (1967) Adult acquired toxoplasmosis. Abstracted, Ann. intern. Med. 66, 1046.

319. NeU, H.C. (1967) Toxoplasmosis transmitted at $\mathbb{\mathbb { Q }}$ autopsy. J. Amer. med. Ass. 202, 844.

320. Kalmanson, G.M., Hubert, E.G. \& Montgomerie, J.Z. (1967) Effect of serum on microbial protoplasts. Ann. intern. Med. 66, 1046.

321. Johnson, J.E. \& Kadull, P.J. (1967) Rocky Mountain $\vec{\omega}$ spotted fever acquired in a laboratory. New Engl. J. S Med. 277, 843.

322. Hammon, W.M. (1968) Human infection acquired in the laboratory. J. Amer. med. Ass. 203, 647.

323. DiesCH, S.L. et al. (1967) Human leptospirosis acquired from squirrels. New Engl. J. Med. 276, 838.

324. HaRland, W.A. \& LeE, F.D. (1967) Intestinal spirochaetosis. Brit. med. J. ii, 718.

325. ReimanN, H.A. (1965) Microbic phagocytosis by enteric epithelial cells. J. Amer. med. Ass. 192, 1130.

326. MoRs, W.B. et al. (1967) Chemoprophylactic agent in schistosomiasis: 14, 15-epoxygeranilgeraniol. Science, 157, 950.

327. Schistosomes strained out of patients' blood. (1967) $\vec{\bullet}$ Med. Wld News, 8, 24.

328. Cahill, K.M. (1967) Thiabendazole in massike strongyloidiasis. Amer. J. trop. Med. Hyg. 16, 451.

329. Deller, J.J. \& Russell, P.K. (1967) An analysis fevers of unknown origin in American soldiers in Vietnam. Ann. intern. Med. 66, 1129.

329a. Deller, J.J. \& Russell, P.K. (1968) Chikungunya disease. Amer. J. trop. Med. Hyg. 17, 107.

330. Janssen, W.A. \& Meyers, C.D. (1968) Fish: Serologic evidence of infection with human pathogens. Science, 159, 547.

331. Brock, T.D. (1967) Life at high temperatures. Science, 158, 1012. 